\title{
Ensino Médio: manuais voltados para o ensino de Filosofia
}

\author{
Américo Grisotto \\ professor da Universidade Estadual de Londrina
}

\section{RESUMO}

No presente texto, não tivemos apenas o intuito de expor um número razoável de propostas didáticas voltadas para ensino de Filosofia no Brasil, mas o de indicar que tais propostas não são isentas quanto ao modo como o ensino de Filosofia é pensado e praticado atualmente em muitas de nossas escolas de ensino médio. Assim, se os manuais de ensino de Filosofia aqui expostos não consistem apenas no que os autores, através do mercado editorial, colocam à nossa disposição, mas manifestações estratégicas do que seja a Filosofia e o seu ensino, será possível, através desses registros, tanto nos situarmos no presente cenário, quanto pensarmos estrategicamente novas possibilidades de criação no seu interior.

Palavras-chave: Ensino de Filosofia; Livros didáticos; Ensino Médio.

\section{RÉSUMÉ}

Dans ce texte, notre objectif n'était pas seulement exposer un bon nombre de propositions visant à l'enseignement didactique de la Philosophie au Brésil, mais pour indiquer que de telles propositions ne sont pas neutres de la façon dont l'enseignement de la Philosophie est pensé et pratiqué actuellement en beaucoup de nos écoles secondaires. Ainsi, si les manuels d'enseignement de la philosophie présentées ici ne consiste pas seulement en ce que les auteurs, par le biais du marché de l'édition, nous avons mis à notre disposition, mais manifestations stratégiques de ce qui sont la Philosophie et son enseignement, il sera possible, à travers ces registres, à la fois se situer dans ce scénario, combien se penser stratégiquement nouvelles possibilités de création dans son intérieur. Mots-clés: Enseignement de la Philosophie; Les manuels scolaires; L'école secondaire (Lycée).

Filosofia e Educação - ISSN 1984-9605 - v. 4, no 1, abril-setembro de 2012 


\section{A título de introdução}

propósito dos manuais didáticos, podemos considerá-los,
basicamente, como instrumentos da didática escolar que enunciam,
numa linguagem que se pretende acessível e clara, conteúdos descritivos e explicativos relativos a uma determinada disciplina ou área do conhecimento. Numa acepção mais atual, tais conteúdos vêm reunidos em unidades ou capítulos e acompanhados de um conjunto amplo de atividades de estudo e de aplicação compreendendo questões, registros de leitura, textos complementares, orientações bibliográficas etc.

É curioso notar que esses materiais talvez sejam uma das modalidades mais antigas da expressão escrita e isso sem tomá-los como uma condição imprescindível para o desenvolvimento da célebre atividade escolar, por meio da qual o conhecimento foi, historicamente, sistematizado, apreendido e socializado entre as gerações.

A título de explanação, cabe ressaltar que o surgimento do livro didático pode remeter a dados mais remotos, e "[...] em certo sentido pode-se considerar a PoÉtica, de Aristóteles, um ancestral seu, já que resulta de notas das aulas ministradas pelo filósofo, em pleno século IV a.C."1 (LAJOLO e ZILBERMAN, 2003, p. 120).

No entanto, pelo caráter tanto de objeto de uso quanto de não exigir, passado o prazo de validade, os costumeiros cuidados de conservação, esses livros contam com uma história esquecida e minimizada. Assim:

\footnotetext{
1 "Se este exemplo pode constranger, citemos a Institutio Oratoria, de Marcus Fabius Quintiliano, professor atuante no século I d.C., que, no décimo livro dessa obra inseriu uma apreciação sumária dos principais autores gregos e latinos, menos como resumo bibliográfico do que como esboço de uma espécie de 'biblioteca mínima' do aluno de Retórica" (LAJOLO e ZILBERMAN, 2003, p. 120).
}

Filosofia e Educação - ISSN 1984-9605 - v. 4, no 1, abril-setembro de 2012 
Apesar do berço ilustre, contudo, o livro didático é o primo-pobre da literatura, texto para ler e botar fora, descartável porque anacrônico: ou ele fica superado dados os progressos da ciência a que se refere ou o estudante o abandona, por avançar em sua educação (LAJOLO e ZILBERMAN, 2003, p. 120).

Mas se a questão não for encerrar por aí as circunstâncias desse velho instrumento e se considerar um outro lado da querela, relativa aos fatores que tornam essa ferramenta de trabalho disponível, o livro didático seria:

[...] o primo-rico das editoras: as primeiras e as mais antigas já o incluíam em seus catálogos, e as atuais e mais modernas sonham com dispor de um ou mais títulos adotados por professores, escolas ou Secretarias de Educação. A vendabilidade do didático é certa, conta com o apoio do sistema de ensino e o abrigo do Estado, é aceita por pais e educadores. Editor nenhum o ignora, embora nem sempre o tenha a seu alcance (LAJOLO e ZILBERMAN, 2003, p. 120-121).

Seja qual for seu viés, tanto de um conteúdo sistematizado do conhecimento que se apresenta ao estudante propiciando-lhe serventia na formação quanto como produto volátil do qual as editoras se servem para ampliar seus recursos, de alguma maneira esses materiais encontram-se esparramados pelo mercado editorial e nos acervos de nossas instituições de formação, aguardando a escolha dos interessados, e que, uma vez escolhidos, passam a ganhar algum tipo de movimento no interior das salas de aula.

Filosofia e Educação - ISSN 1984-9605 - v. 4, no 1, abril-setembro de 2012 
A esse respeito, o material ${ }^{2}$ que será exposto a seguir consiste numa coletânea $^{3}$ de livros didáticos do que se oferece hoje, nas últimas séries da educação básica, quando a questão é o ensino de Filosofia no Brasil.

$\mathrm{Na}$ realidade, estão aqui reunidos um número significativo de manuais ${ }^{4}$ que o professor de Filosofia do Ensino Médio encontra disponíveis em livrarias, bibliotecas, lojas de livros usados $^{5}$, e podem servir tanto de informação a respeito de como o ensino de Filosofia tem sido entendido e ministrado, quanto de parâmetro didático/metodológico na elaboração das aulas, configurando-se como um conjunto de ferramentas de trabalho a serem perscrutas.

A propósito, nesse aspecto do que deve ser sondado pelo professor, especificamos num determinado momento do texto a respeito de uma certa orientação a que pertencem estes manuais como forma de sistematizar, de alguma maneira, a sua exposição; concretamente caberá ao profissional envolvido diretamente com o ensino da Filosofia o exercício de compor as suas próprias referências e o seu material de trabalho.

\footnotetext{
${ }^{2}$ Esse levantamento dos livros didáticos voltados para o Ensino Médio no Brasil remete ao final do ano de 2006 e início de 2007.

3 Neste aspecto, embora tenhamos nos esforçado em abarcar o máximo dos manuais disponíveis, é bem possível que alguns não se encontrem aqui presentes. A maior dificuldade que encontramos quanto a este acesso diz respeito, principalmente, à distribuição dos mesmos, ou a sua presença nas livrarias, e em segundo lugar à disponibilidade dos mesmos no acervo das principais bibliotecas. Vale frisar, também, que não recebemos gratuitamente nenhum destes materiais para que essa exposição pudesse ser realizada. Todos manuais aqui expostos, ou foram adquiridos, ou foram acessados no acervo das bibliotecas.

${ }^{4}$ Haja vista que o nosso propósito não se estendeu para além de uma exposição panorâmica desses materiais, nos limitamos apenas em oferecer os seus principais tópicos, ou um esqueleto das obras (chamada das suas unidades, capítulos, textos complementares, bibliografia etc.), o que exigirá dos que se interessarem o acesso pormenorizado.

5 Como há essa possibilidade de aquisição, numa rede de serviços que aumentou consideravelmente no Brasil nos últimos anos, não nos preocupamos apenas em expor as obras mais recentes. Aliás, por conta da atual presença da Filosofia nos currículos, algumas dessas obras vêm sendo reeditadas.
}

Filosofia e Educação - ISSN 1984-9605 - v. 4, no 1, abril-setembro de 2012 
Desse modo, porque atentos à possibilidade da construção de novos estilos do filosofar e do ensinar a filosofar por meio ou para além dos materiais já existentes é que apresentamos o quadro dessas publicações.

Aliás, em se tratando dos manuais aqui reunidos, nossa tentativa não foi de analisá-los, ou avaliá-los, mas trazê-los, na sua diversidade, à superfície. Permitir que uma porção representativa do que se produz atualmente nesse âmbito, pudesse não apenas ser agrupada, mas que, de alguma forma, fosse oferecida como material de consulta aos interessados.

Por esse motivo, os professores não terão à frente, neste registro, uma discussão teórica e metodológica a respeito do ensino de Filosofia, mas um acesso a informações de caráter geral.

É bom lembrar que a ideia inicial desse trabalho e que acabou chegando a efeito, foi a de que se oferecesse aos professores principiantes - principalmente aqueles recém-saídos das licenciaturas em Filosofia - um cenário dos textos didáticos, de modo que não só se situassem e adquirissem informações quanto à existência desses materiais, mas que pudessem, por conta própria, ir pautando-se no que já se disponibiliza nessa esfera - à procura dos instrumentos de trabalho que melhor atendessem os seus propósitos de ensino.

Como já tínhamos mencionado, é importante salientar mais uma vez que o conjunto dos manuais aqui reunidos, além de serem portas de acesso à compreensão que se tem hoje do que seja o ensino de Filosofia, constituem, também, portas de acesso para se conhecer o rumo que o ensino de Filosofia tem tomado nos últimos anos, ou que pode tomar daqui em diante, isto é, são propostas que intentam viabilizar uma determinada ação em relação ao ensino; autores a serviço de um projeto específico do que seja o pensamento em Filosofia através das atividades de ensino.

Filosofia e Educação - ISSN 1984-9605 - v. 4, no 1, abril-setembro de 2012 
No que se refere aos materiais propriamente ditos, muitos deles ganharam, provavelmente pela sequência das edições, bem como pelo auxílio das equipes envolvidas no trabalho de confecção, uma configuração bastante abrangente e complexa, mas não constituem uma produção sobre-humana. Surgiram das inquietações e do consequente empenho produtivo quer de pensadores em particular quer de grupos de estudo em Filosofia, o que não impede que outras tantas propostas se manifestem e tornem esse cenário das produções didáticas um cenário ainda mais rico e diversificado.

Por fim, vale destacar que nas últimas décadas avançamos muito nessa direção da produção dos materiais para a sala de aula, o que quer dizer, também, que o ensino de Filosofia no Brasil vem ganhando contornos bastante interessantes e se constitui num importante e promissor campo de estudo, de pesquisa e de expressão de propostas pedagogicamente filosóficas.

Desejamos de fato que, com essa iniciativa, os profissionais do ensino de Filosofia não apenas tomem conhecimento dos materiais que o mercado editorial tem oferecido ao ensino de Filosofia, mas que forjem, por iniciativa própria, os instrumentos didáticos e metodológicos que melhor ofereçam a si próprios e aos estudantes a possibilidade de pensar no âmbito da Filosofia.

\section{Ensino de Filosofia: a história da Filosofia ${ }^{6}$ como centro}

Tendo em vista os manuais ${ }^{7}$ que se seguem, a visão histórica da Filosofia foi tomada como centro, o que significa que os autores seguem a tendência de

\footnotetext{
${ }^{6}$ A seguir, quanto à utilização que se faz da história da Filosofia nos livros didáticos para o Ensino Médio, nos serviremos das denominações centro e referencial, sugeridas por Franklin Leopoldo e Silva (1986, p. 153-162), no seu texto "História da Filosofia: centro ou referencial?", presente na coletânea $O$ Ensino da Filosofia no $2^{\circ}$. Grau organizada por Henrique Nielsen Neto.

${ }^{7}$ A ordem de exposição dos manuais nesse tópico e nos que se seguem, não obedecendo nenhuma ordem de importância, de cronologia etc., foi aleatória.
}

Filosofia e Educação - ISSN 1984-9605 - v. 4, no 1, abril-setembro de 2012 
localizar os pensadores e os sistemas na ordem histórica, cronológica do seu desenvolvimento, objetivando sob essa ótica familiarizar os alunos com os problemas filosóficos e as suas formas de solução; uma orientação, ou escolha filosófica diante da qual os autores se colocam com maior gravidade, tomando a herança do pensamento histórico em Filosofia e a própria Filosofia como

[...] uma manifestação cultural que se apresenta ao longo do tempo, fruto da reação do pensamento humano perante os acontecimentos presentes nos diferentes momentos do processo histórico e social, que evolui e se transforma continuamente. À medida que procura evidenciar a maneira peculiar como cada homem foi enfrentando os problemas apresentados no decurso de sua existência, essa abordagem incita o aluno a encarar o ato de filosofar como resposta criativa aos problemas e situações novas" (SEVERINO apud SOUZA, 1995, p. 10).

Em direção a esta abordagem, temos o manual proposto pelo autor César Apareciddo Nunes ${ }^{8}$ intitulado Aprendendo Filosofia, lançado pela editora Papirus e faz parte da coleção "Educar Aprendendo".

Quanto à sua exposição, este material, além de contar com prefácio, apresentação, conclusão geral, bibliografia e dados do autor, acompanha a Filosofia da origem à sua configuração contemporânea a partir da seguinte estrutura:

Capítulo I: As origens da Filosofia - o período cosmológico (a Filosofia dos físicos da Jônia, a escola pitagórica, os eleatas, Heráclito e a dialÉtica, os filósofos atomistas), o período antropológico e clássico (os sofistas, Sócrates, Platão e o platonismo, Aristóteles, o prenúncio da decadência), o período decadente e o cristianismo (a ideologia cristã, o triunfo histórico do Cristianismo).

Capítulo II: A Filosofia medieval (introdução á idade média, considerações gerais, a

${ }^{8}$ Professor doutor da Faculdade de Educação da Unicamp, coordenador do Grupo de Estudos e Pesquisa em Filosofia da Educação PAIDÉIA e diretor da Associação Brasileira de Educação Sexual (Abrades).

Filosofia e Educação - ISSN 1984-9605 - v. 4, no 1, abril-setembro de 2012 
queda de Roma, a Filosofia medieval (conceito), a obra de Santo Agostinho (a patrística), a obra de Santo Tomás de Aquino - a escolástica).

Capítulo III: A Filosofia moderna - a ruptura filosófica (o mundo moderno, o racionalismo nascente, o mundo autogovernado (o mecanicismo), o empirismo, o idealismo alemão: Immanuel Kant, a sociedade moderna) a ruptura política (Thomas Hobbes, John Locke, Montesquieu).

Capítulo IV: A Filosofia contemporânea (introdução, a Filosofia da vida, o pragmatismo, a fenomenologia, o existencialismo, o marxismo, a Filosofia da ciência e a linguagem, como explicar a validade da Filosofia hoje, na sociedade tecnocrática).

Como sugestão de atividades, compondo o término de cada parte, ou capítulo, verifica-se a presença de uma breve cronologia e um tópico denominado "Para sua reflexão...", em que são oferecidas questões ao aluno. Encerrando a exposição dos conteúdos, é possível contar com um glossário bastante sucinto e bibliografia referente à introdução em Filosofia, bem como os seus períodos históricos da tradição filosófica.

Um outro texto, em sua segunda edição ampliada, é o Vivendo a Filosofia de autoria de Gabriel Chalita ${ }^{9}$, lançado pela editora Atual em 2004.

Em termos gerais, esse texto conta com apresentação inicial, quatro unidades divididas em capítulos, bibliografia final compreendendo uma lista de dicionários de Filosofia; livros de introdução ao estudo da Filosofia; estudos sobre história do pensamento e clássicos da Filosofia, bem como um índice remissivo. O conteúdo, que se encontra dividido nas unidades "O nascimento da razão", "Entre a razão e a fé", "A supremacia da razão", "A razão em cheque", recebe as especificações do quadro que se segue:

Unidade 1

Introdução: O princípio; Nasce a civilização; A expansão do mundo grego.

Capítulo 1: O domínio dos deuses; O mistério da natureza; Os deuses, parceiros dos gregos.

${ }^{9}$ Doutor em Comunicação e Semiótica e em Direito. Mestre em Ciências Sociais e em Direito. Bacharel em Direito e em Filosofia. Professor dos programas de graduação e pós-graduação em Direito da PUC-SP.

Filosofia e Educação - ISSN 1984-9605 - v. 4, no 1, abril-setembro de 2012 
Capítulo 2: Os filósofos da natureza; A primavera da razão; Os jônios; Os pitagóricos; Os eleatas; Os pluralistas.

Capítulo 3: Os mestres do pensamento; Os sofistas; Sócrates, Platão e Aristóteles.

Capítulo 4: A Filosofia helenística; As novas fronteiras do pensar; O ceticismo; O cinismo; O epicurismo; O fim da Antiguidade e as novas preocupações filosóficas.

Unidade 2

Introdução: Todos os caminhos partem de Roma; Da república ao poderoso império; A ditadura de Júlio César; Roma imperial; Uma religião no meio do caminho; Um império em crise; A Igreja inspira o Império.

Capítulo 5: $\mathrm{O}$ advento da patrística; $\mathrm{O}$ cristianismo e a Filosofia; Os padres apologistas; o gnosticismo; A escola de Alexandria e Orígenes.

Capítulo 6: Corações inquietos; Santo Ambrósio, o "estadista" da Igreja; Santo Agostinho.

Capítulo 7: Entre a patrística e a escolástica; A dispersão da Filosofia; Boécio; João Escoto Erígena; A Filosofia além do cristianismo; Avicena, pensador do Oriente; Averróis: pensador do Ocidente; Entre os judeus espanhóis: Maimônides; Santo Anselmo.

Capítulo 8: O advento da escolástica; Entre a fé e a razão; Pedro Abelardo; Duns Escoto e Roger Bacon; Guilherme de Ockham.

Capítulo 9: A cristianização de Aristóteles; Santo Alberto Magno; São Tomás de Aquino.

Unidade 3

Introdução: $\mathrm{O}$ nascimento da modernidade; A revolução comercial; Formação e fortalecimento dos Estados nacionais; A sociedade moderna; A crise da Igreja; O renascimento.

Capítulo 10: Os utopistas; A concepção tradicional de política; Thomas Morus; Tommaso Campanella; Francis Bacon.

Capítulo 11: A justificação do Estado moderno; Nicolau Maquiavel; Thomas Hobbes. Capítulo 12: As origens da ciência moderna; A contribuição renascentista; Ciência, misticismo e magia; Giordano Bruno; Francis Bacon.

Capítulo 13: O grande racionalismo; A importância da razão; René Descartes; Baruch Espinosa; Gottfried Leibniz.

Capítulo 14: O empirismo inglês; A importância da experiência; John Locke; George Berkeley e David Hume.

Capítulo 15: O iluminismo; Materialismo e sensacionismo; Educação e progresso; O liberalismo na França: Voltaire e Montesquieu; Jean-Jacques Rousseau; Immanuel Kant.

Unidade 4

Introdução: O mundo em movimento; Novos processos produtivos; Uma nova ordem política; Capital e trabalho; Um século de conflitos; O novo universo artístico; $\mathrm{O}$

Filosofia e Educação - ISSN 1984-9605 - v. 4, no 1, abril-setembro de 2012 
século dos extremos.

Capítulo 16: Os seguidores e os críticos de Kant; Idealistas e realistas; Fichte e Schelling; Georg Hegel; Sören Kierkegaard e a crítica ao realismo; Arthur Schopenhauer; Friedrich Nietzsche.

Capítulo 17: O marxismo; Ludwig Feuerbach; Karl Marx.

Capítulo 18: O positivismo; Filosofia e ciências naturais; John Stuart Mill; Augusto Comte; Émile Durkheim; O positivismo no século XX: Bertrand Russel; Ludwig Wittgenstein; Rudolf Carnap e o Círculo de Viena; Karl Popper.

Capítulo 19: O existencialismo; Ser no mundo; Jean Paul Sartre; Martin Heidegger.

Capítulo 20: A fenomenologia e as teorias da comunicação; A procura da essência: Edmund Husserl; A escola de Frankfurt: Max Horkheimer; Max Horkheimer e Theodor Adorno; Walter Benjamin; Herbert Marcuse; Jürgen Habermas; PósModernismo: Lyotard e Rorty.

Tanto a parte introdutória dos textos quanto os capítulos contam com alguns destaques como: citações; ilustrações com esclarecimentos e esquemas explicativos que se estendem com apresentação de vocabulário e exposição de mapas; espaços reservados à conexões filosóficas, com exposição de trechos de textos relacionando a literatura em geral com os textos expostos, e, por fim, como atividade de recapitulação a proposta de análise, crítica e reflexão do que se expôs, duas seções: "Para discutir e escrever", com atividades quanto à fixação e problematização dos materiais propostos, e "Interpretando", sugerindo atividades de escrita reflexiva, tomando um, ou mais textos relacionados ao contex to do que se desenvolveu em cada capítulo.

Voltado para os alunos do atual Ensino Médio, mas também destinado aos alunos dos cursos de graduação que oferecem a disciplina de Filosofia nos primeiros anos, o manual Curso de Filosofia: para professores e alunos dos cursos de segundo grau [sic] e de graduação ${ }^{10}$, trata-se de uma proposta para o

\footnotetext{
${ }^{10}$ A nosso ver, esse acréscimo em relação às obras anteriores não impede que ela componha a relação que disponibilizamos. Dentre outros motivos, é bom que se diga que até a não vigência da lei que tornou obrigatória a disciplina de Filosofia no Ensino Médio, a socialização dos seus conhecimentos não destoava, e ainda hoje não destoa tanto, daqueles oferecidos nos primeiros anos de alguns cursos de graduação. Aliás, ainda que muitos dos autores aqui presentes não tenham colocado em destaque, ou se utilizado dessa possibilidade, antes que a disciplina de Filosofia se fizesse presente nos currículos da educação básica, boa parte dos alunos a
}

Filosofia e Educação - ISSN 1984-9605 - v. 4, no 1, abril-setembro de 2012 
ensino de Filosofia organizado por Antonio Rezende ${ }^{11}$. Lançado pela editora Zahar encontrava-se em 2005 na sua $13^{a}$ edição. Além de quem o organiza, são seus autores: Maura Iglésias ${ }^{12}$, José Américo Pessanha ${ }^{13}$, Maria do Carmo Bettencout de Faria $^{14}$, José Silveira da Costa ${ }^{15}$, Hilton Japiassú ${ }^{16}$, Danilo Marcondes $^{17}$, Valerio Rohden ${ }^{18}$, Maria Célia Simon ${ }^{19}$, Franklin Trein ${ }^{20}$, Wilmar do Valle Barbosa ${ }^{21}$, Leda Miranda Huhne ${ }^{22}$, Vera Portocarrero ${ }^{23}$, Gerd Bornheim $^{24}$, Vera Cristina de Andrade Bueno ${ }^{25}$, Luiz Carlos Pereira ${ }^{26}$, Eduardo Jardim de Moraes $^{27}$, Kátia Muricy ${ }^{28}$.

Recebendo logo de início uma apresentação do autor que coordena a obra, além de uma introdução assinada pela autora do primeiro capítulo, traz na sua estrutura geral um conteúdo dividido em dezesseis capítulos:

\begin{tabular}{l|l}
$\begin{array}{l}\text { Introdução - O que é Filosofia e para que } \\
\text { serve }^{29}\end{array}$ & 9. Hegel e a DialÉtica \\
\hline
\end{tabular}

acessavam de fato no primeiro ano de alguns cursos de graduação, cuja abordagem atende à formação geral (Filosofia, sociologia, psicologia e um montante de disciplinas complementares em tom introdutório). Em outras palavras, não é difícil encontrarmos ainda hoje, num primeiro contato do aluno de graduação com essa tradição do pensamento, a prática, sob a orientação dos professores, de utilizarem-se desses materiais didáticos, ainda que produzidos na sua imensa maioria para a fase anterior correspondente à instrução básica.

${ }^{11}$ Professor de Filosofia da PUC/RJ e do Centro Educacional de Niterói (CEN).

${ }^{12}$ Professora de Filosofia da PUC/RJ.

${ }^{13}$ Professor de Filosofia da UFRJ.

${ }^{14}$ Professora de Filosofia da UFRJ.

${ }^{15}$ Professor de Filosofia da UFRJ.

${ }^{16}$ Professor de Filosofia da UFRJ.

${ }^{17}$ Professor de Filosofia da PUC/RJ e UFF.

${ }^{18}$ Professor de Filosofia da UFRGS.

${ }^{19}$ Professora de Filosofia da USU.

${ }^{20}$ Professor de Filosofia da UFRJ.

${ }^{21}$ Professor de Filosofia da UFRJ.

${ }^{22}$ Professora de Filosofia da USU.

${ }^{23}$ Professora de Filosofia da USU.

${ }^{24}$ Professor de Filosofia da UFRJ.

${ }^{25}$ Professora de Filosofia da PUC/RJ e da UFF.

${ }^{26}$ Professor de Filosofia da Unicamp e PUC/RJ.

${ }^{27}$ Professor de Filosofia da PUC/RJ.

${ }^{28}$ Professora de Filosofia da PUC/RJ.

Filosofia e Educação - ISSN 1984-9605 - v. 4, no 1, abril-setembro de 2012 


\begin{tabular}{|c|c|}
\hline 1. Pré-socráticos: físicos e sofistas ${ }^{31}$. & 10. O Materialismo Histórico ${ }^{32}$ \\
\hline 2. Platão e as Ideias ${ }^{33}$ & 11. O Irracionalismo de Kierkegaard ${ }^{34}$ \\
\hline 3. O Realismo Aristotélico ${ }^{35}$ & 12. Nietzsche: uma crítica radical ${ }^{36}$ \\
\hline 4. A Filosofia Cristã $\tilde{a}^{37}$ & 13. O Existencialismo de Sartre $^{38}$ \\
\hline 5. O Racionalismo Cartesiano ${ }^{39}$ & 14. A Filosofia Analítica ${ }^{40}$ \\
\hline 6. O Empirismo Inglês ${ }^{41}$ & 15. Visões da Modernidade ${ }^{42}$ \\
\hline 7. O Criticismo Kantiano ${ }^{43}$ & 16. A Filosofia no Brasil ${ }^{44}$ \\
\hline 8. O Positivismo de Comte C5 $^{45}$ & \\
\hline
\end{tabular}

Cada qual dos capítulos acima elencados apresenta ao final e a título de esclarecimento, as palavras-chave de que se utilizou o autor em seu texto, bem como um conjunto de questões relativas ao seu conteúdo, bem como temas para debate. Permeando o desenvolvimento de cada tópico dos capítulos propostos, os autores se utilizam de textos filosóficos traduzidos do original.

Ao final da obra ganham destaque um vocabulário de termos mais usados em Filosofia elaborado por Hilton Japiassu e um índice onomástico.

O trabalho Construindo Ética e Cidadania Todos os Dias: reflexões sobre temas filosóficos, sociais, políticos, econômicos e históricos ${ }^{46}$ de autoria de

\footnotetext{
${ }^{29}$ Autoria de Maura Iglésias.

${ }^{30}$ Autoria de Franklin Trein.

${ }^{31}$ Autoria de Maura Iglésias.

${ }^{32}$ Autoria de Wilmar do Valle Barbosa

${ }^{33}$ Autoria de José Américo Pessanha.

${ }^{34}$ Autoria de Leda Miranda Huhne

${ }^{35}$ Autoria de Maria do Carmo Bettencourt de Faria.

${ }^{36}$ Autoria de Vera Portocarrero.

${ }^{37}$ Autoria de José Silveira da Costa.

${ }^{38}$ Autoria de Gerd Bornheim.

${ }^{39}$ Autoria de Hilton Japiassú.

${ }^{40}$ Autoria de Vera Cristina de Andrade Bueno e de Luiz Carlos Pereira

${ }^{41}$ Autoria de Danilo Marcondes.

${ }^{42}$ Autoria de Eduardo Jardim de Moraes e de Kátia Muricy.

${ }^{43}$ Autoria de Valerio Rohden.

${ }^{44}$ Autoria de Antonio Rezende.

${ }^{45}$ Autoria de Maria Célia Simon.

${ }^{46}$ Esse manual, por atender a uma abordagem mais temática tomando a história da Filosofia como referencial, será apresentado posteriormente no tópico que lhe corresponde.
}

Filosofia e Educação - ISSN 1984-9605 - v. 4, no 1, abril-setembro de 2012 
Mauri Luiz Heerdt ${ }^{47}$ e publicado pela editora Sophos, é recomendado por seus editores para a $1^{\mathrm{a}}$ série do Ensino Médio sugerindo uma abordagem mais temática do ensino de Filosofia e seria complementado pelo trabalho que se segue Pensando para viver: alguns caminhos da Filosofia, do mesmo autor, publicado em 2005 e em sua $5^{a}$ edição, cuja abordagem toma a história da Filosofia como centro e consiste em dois volumes, dirigidos respectivamente aos dois últimos ano do Ensino Médio.

O seu conteúdo:

Filosofia ou filosofar?; Filosofia e conhecimento; Mitologia e Filosofia; Os pré-socráticos; a democracia e os sofistas; Sócrates de Atenas; Platão de Atenas; Aristóteles de Estagira; O Helenismo e a Filosofia pós-socrática;
Filosofia e cristianismo; A Filosofia na Idade Média; O Renascimento e a Filosofia Moderna; O Racionalismo... (são no total 23 capítulos que abordam as várias correntes filosóficas, segundo informação dos editores no catálogo da editora).

Cada capítulo traz a reflexão sobre uma corrente filosófica, um filósofo representativo de tal corrente e um breve texto do filósofo em questão. No final dos capítulos, na tentativa de ilustrar os conteúdos propostos, há exercícios de pesquisa, revisão e reflexão, permitindo tanto rever quanto aprofundar, e atualizar os conteúdos estudados.

A seguir, os dois manuais a serem expostos consistem em traduções e são eles História da Filosofia do inglês Bryan Magee ${ }^{48}$, publicado pela editora Loyola em sua terceira edição e o Livro Completo da Filosofia: entenda os

\footnotetext{
${ }^{47}$ Mestre pela Universidade Federal de Santa Catarina (UFSC). Professor de Ensino Superior da Unisul.

${ }^{48}$ Este manual não apresenta informações detalhadas a respeito da formação, ou percurso acadêmico de seu autor, apenas que se trata de um filósofo respeitado em seu país, escritor e apresentador de televisão.
}

Filosofia e Educação - ISSN 1984-9605 - v. 4, no 1, abril-setembro de 2012 
conceitos básicos dos grandes pensadores: de Sócrates a Sartre do americano James Mannion.

O primeiro deles, no que lhe diz respeito aos conteúdos, apresenta-os em sucessão histórica a partir de nove assuntos: "Os Gregos e seu Mundo", "Cristianismo e Filosofia", "Os Inícios da Ciência Moderna”, "Os Grandes Racionalistas", "Os Grandes Empiristas", "Os Pensadores Revolucionários Franceses", "O Século de Ouro da Filosofia Alemã", "Democracia e Filosofia", "A Filosofia do Século XX", com seus respectivos tópicos de desenvolvimento:

\begin{tabular}{|c|c|c|c|}
\hline $\begin{array}{l}\text { 1. Antes de Sócrates; } \\
\text { Sócrates, } \\
\text { Aristóteles; Os Cínicos; } \\
\text { Os Céticos; Os } \\
\text { Epicuristas; Os Estóicos. }\end{array}$ & $\begin{array}{l}\text { 4. Descartes; } \\
\text { Leibniz. }\end{array}$ & Spinoza; & $\begin{array}{l}\text { 7. Kant; Schopenhauer; } \\
\text { Comparações entre } \\
\text { e Oriente } \\
\text { Schelling; Hegel; Marx; } \\
\text { Nietzsche. }\end{array}$ \\
\hline $\begin{array}{l}\text { 2. Santo Agostinho; } \\
\text { Filosofia Medieval. }\end{array}$ & $\begin{array}{l}5 . \quad \text { Locke; } \\
\text { Hume; Burke. }\end{array}$ & Berkeley; & $\begin{array}{l}\text { 8. Os Utilitaristas; Os } \\
\text { Pragmatistas Americanos. }\end{array}$ \\
\hline $\begin{array}{l}\text { 3. De Copérnico a } \\
\text { Newton; Maquiavel; } \\
\text { Francis Bacon; Hobbes. }\end{array}$ & $\begin{array}{l}\text { 6. Voltaire; } \\
\text { Rousseau. }\end{array}$ & Diderot; & $\begin{array}{l}\text { 9. Frege e a Lógica } \\
\text { Moderna; Russell e a } \\
\text { Filosofia } \\
\text { Wittgenstein e a Filosofia } \\
\text { da } \\
\text { Existencialismo; Bergson e } \\
\text { a Recente Finguagem; } \\
\text { Francesa; Popper; O Futuro } \\
\text { da Filosofia. }\end{array}$ \\
\hline
\end{tabular}

Ocupando a última parte do livro encontram-se o glossário, um guia de leitura, e um índice.

No entanto, a contribuição maior deste livro, além da qualidade da sua impressão, se deve a um conjunto bastante diversificado de ilustrações.

Temos por fim, dos manuais traduzidos, o que nos propõe James Mannion $^{49}$ com o seu Livro Completo da Filosofia: entenda os conceitos

${ }^{49}$ Editor profissional e autor de vários livros. Vive no Bronx, em Nova Iorque.

Filosofia e Educação - ISSN 1984-9605 - v. 4, no 1, abril-setembro de 2012 
básicos dos grandes pensadores: de Sócrates a Sartre publicado pela editora Madras.

A distribuição dos conteúdos, nesse livro, consiste numa brevíssima introdução seguida do desenvolvimento curto de vinte e cinco capítulos segundo os períodos históricos da tradição filosófica.

\begin{tabular}{|c|c|c|}
\hline 1. Para mim, isso é grego & 10. O Empirismo Inglês & $\begin{array}{lcc}19 . \quad \text { Escolas } & \text { do } \\
\text { Pensamento Orientais } & \end{array}$ \\
\hline $\begin{array}{lcr}\text { 2. Os } & \text { Três Sábios: } \\
\text { Sócrates, } & \text { Platão } \quad \text { e } \\
\text { Aristóteles } & & \end{array}$ & 11. O Iluminismo Francês & $\begin{array}{l}\text { 20. As Três Grandes } \\
\text { Religiões }\end{array}$ \\
\hline $\begin{array}{l}\text { 3. O Declínio e a Queda } \\
\text { do Período Helenístico }\end{array}$ & 12. O Idealismo Germânico & $\begin{array}{l}\text { 21. Objetivismo e o Meio } \\
\text { de Vida Correto }\end{array}$ \\
\hline $\begin{array}{lcc}4 . & \text { A } & \text { Mentalidade } \\
\text { Medieval } & \\
\end{array}$ & 13. O Utilitarismo & $\begin{array}{lrr}22 . & \text { Os } & \text { Filósofos } \\
\text { Esquecidos } & \\
\end{array}$ \\
\hline $\begin{array}{lcc}5 . \quad \mathrm{O} & \text { Período } & \text { da } \\
\text { Renascença } & & \\
\end{array}$ & $\begin{array}{l}\text { 14. Os Transcendentalistas } \\
\text { Americanos }\end{array}$ & $\begin{array}{l}\text { 23. Doze Passos para uma } \\
\text { Vida Melhor }\end{array}$ \\
\hline 6. Humanismo & $\begin{array}{l}\text { 15. Fenomenologia } \mathrm{e} \\
\text { Existencialismo }\end{array}$ & $\begin{array}{l}\text { 24. Tudo o que é Antigo é } \\
\text { Nova Era Outra Vez }\end{array}$ \\
\hline 7. A Reforma Protestante & $\begin{array}{l}\text { 16. Filosofias Modernas e } \\
\text { Pós-Modernas }\end{array}$ & 25. Filosofia e o Ócio \\
\hline 8. A Revolução Científica & $\begin{array}{l}\text { 17. Sociologia } \\
\text { Antropologia }\end{array}$ & \\
\hline $\begin{array}{l}\text { 9. A Aproximação dos } \\
\text { Tempos Modernos }\end{array}$ & 18. Psicologia & \\
\hline
\end{tabular}

Todos estes capítulos, além de uma sucinta introdução, vêm ilustrados por pequenas chamadas no seu interior, com aquilo que o autor considera: "Fato", "Essencial", "Alerta", "Questões", cuja intenção visa exercitar, ou fixar aspectos do conteúdo. Compondo sua parte final encontram-se um apêndice “A”, composto por um Glossário de Termos Filosóficos e um apêndice "B”, em que se apresenta quem é quem na Filosofia. No final podemos contar com um índice remissivo. 


\section{A história da Filosofia como centro e como referencial}

A perspectiva que se segue, numa espécie de revezamento entre a história da Filosofia como centro e a história da Filosofia como referencial, apresenta-se, com mais ou menos ênfase e na totalidade das obras que se seguem, ora pendendo para o percurso do pensamento filosófico ao longo do tempo, ora utilizando-se do ponto de vista desse pensamento apenas como orientação. Em alguns casos, ainda oscilando entre o centro e o referencial, ambos os enfoques se permeiam através de um encaminhamento e de correlações inerentes ao texto, em que o filosofar não só se faz numa configuração histórica em razão dos diferentes momentos do processo histórico e social, mas também através de um esforço de reflexão sobre problemas tomados da experiência cotidiana do aluno em face dos desafios postos tanto pela experiência quanto pela consciência humana na atualidade (SEVERINO apud SOUZA, 1995, p. 10).

Indo de encontro com a essa orientação, o manual Filosofia que apresentamos a seguir é de autoria de Antônio Joaquim Severino ${ }^{50}$. Trata-se da proposta para o ensino de Filosofia no interior da "Coleção Magistério" da "Série Formação Geral" da editora Cortez. Tal iniciativa compõe-se, segundo seus organizadores, por vinte e quatro livros didáticos, destinados tanto para uso dos professores, quanto dos alunos do segundo grau (atualmente Ensino Médio) e da Habilitação no Magistério (antigo curso normal).

A começar pela distribuição proposta no sumário, este manual do ensino de Filosofia se organiza tendo como ponto de partida a apresentação da coleção, seguida da introdução do autor a respeito da proposta, e duas sequências de capítulos divididos em duas unidades.

\footnotetext{
${ }^{50}$ Bacharel e mestre em Filosofia pela Universidade Católica de Louvain, Bélgica (1964); doutorou-se em Filosofia na PUC de São Paulo (1971).
}

Filosofia e Educação - ISSN 1984-9605 - v. 4, no 1, abril-setembro de 2012 
Parte I A gênese antropológica e formação histórica da cultura ocidental

\begin{tabular}{|l|l|}
\hline 1. A consciência como estratégia da vida. & $\begin{array}{l}\text { 6. As pretensões do conhecimento } \\
\text { metafísico e a imagem essencialista do } \\
\text { homem. }\end{array}$ \\
\hline 2. E a consciência se expande. & $\begin{array}{l}\text { 7. A revolução epistemológica e o projeto } \\
\text { iluminista da modernidade. }\end{array}$ \\
\hline $\begin{array}{l}\text { 3. A cultura ocidental e fruto da união de } \\
\text { três pequenos/grandes povos. }\end{array}$ & $\begin{array}{l}\text { 8. A ciência como conhecimento lógico- } \\
\text { experimental do mundo e a visão } \\
\text { naturalista do homem. }\end{array}$ \\
\hline $\begin{array}{l}\text { 4. A expressão cultural da Filosofia no } \\
\text { ocidente. }\end{array}$ & $\begin{array}{l}\text { 9. A Filosofia dialÉtica: retomada, } \\
\text { negação e superação da metafísica e da } \\
\text { ciência. }\end{array}$ \\
\hline 5. A Filosofia e seus modos de pensar. & \\
\hline
\end{tabular}

Parte II As formas de expressão da cultura contemporânea enquanto mediações objetivas da existência humana

\begin{tabular}{|l|l|l|}
\hline $\begin{array}{l}\text { 10. O homem, a natureza e o trabalho: a } \\
\text { ordem econômica da sociedade. }\end{array}$ & $\begin{array}{l}\text { 13. O agir pessoal e a prática social: a } \\
\text { Ética e a política. }\end{array}$ \\
\hline $\begin{array}{l}\text { 11. O homem na ordem política da } \\
\text { sociedade: poder e dominação. }\end{array}$ & $\begin{array}{l}\text { 14. As preocupações temáticas das } \\
\text { tendências atuais da Filosofia. }\end{array}$ \\
\hline $\begin{array}{l}\text { 12. A atividade simbolizadora do } \\
\text { Homem: produção e organização da } \\
\text { cultura. }\end{array}$ & & \\
\hline
\end{tabular}

$\mathrm{Na}$ tentativa de subsidiar o trabalho do professor e dos alunos, este roteiro dos capítulos, de maneira geral, conta com vários esquemas explicativos. Cada capítulo, por sua vez, traz ao seu final atividades de esclarecimento de conceitos, questões para discussão, leituras complementares e referências bibliográficas. No quarto capítulo, em particular, pode ser encontrado um quadro cronológico bastante completo dos pensadores, de suas ideias e das correntes filosóficas. Encerrando o texto temos uma bibliografia geral de apoio aos estudantes e aos professores.

Em continuidade a esta exposição, temos um outro manual voltado para o Ensino Médio e que se encontrava-se, em 2001, em sua $34^{\text {a }}$ edição. Trata-se do texto de autoria de Antonio Xavier Teles ${ }^{51}$, lançado pela editora Ática.

${ }^{51}$ Professor de Ensino Superior e Técnico de Educação (MEC).

Filosofia e Educação - ISSN 1984-9605 - v. 4, no 1, abril-setembro de 2012 
A começar do índice, a sua constituição didática divide-se em três partes: "Filosofia Antiga", "Filosofia Atual” e "Lógica Moderna", contando com uma breve introdução do autor que as antecede. No interior destas partes encontramse os capítulos todos eles inaugurados por, pelo menos, uma frase de algum pensador como motivação inicial.

Primeira Parte

\begin{tabular}{|l|l|l|}
\hline $\begin{array}{l}\text { 1. A Filosofia, ontem e } \\
\text { hoje. }\end{array}$ & 7. Atitude filosófica hindu. & $\begin{array}{l}\text { 13. O problema do } \\
\text { conhecimento humano. }\end{array}$ \\
\hline $\begin{array}{l}\text { 2. Mito, a primeira } \\
\text { explicação da realidade. }\end{array}$ & 8. Atitude chinesa. & $\begin{array}{l}\text { 14. Immanuel Kant, o } \\
\text { filósofo do conhecimento. }\end{array}$ \\
\hline $\begin{array}{l}\text { 3. O momento da } \\
\text { Filosofia. }\end{array}$ & $\begin{array}{l}\text { 9. A Filosofia, hoje, na } \\
\text { China }\end{array}$ & $\begin{array}{l}\text { 15. Nova visão do Real: a } \\
\text { Filosofia dialética. }\end{array}$ \\
\hline $\begin{array}{l}\text { 4. As primeiras tentativas } \\
\text { de construção do } \\
\text { verdadeiro na Grécia. }\end{array}$ & 10. Definição de Filosofia. & 16. Teoria dos valores. \\
\hline $\begin{array}{l}\text { 5. A Filosofia e a Ciência } \\
\text { Gregas. }\end{array}$ & 11. Divisão da Filosofia. & 17. Noções de Estética. \\
\hline $\begin{array}{l}\text { 6. Os grandes sistemas da } \\
\text { Filosofia grega. }\end{array}$ & 12. Filosofia e Ciências. & \\
\hline
\end{tabular}

Segunda Parte

\begin{tabular}{|l|l|l|}
\hline $\begin{array}{l}\text { 1. Uma introdução à } \\
\text { Filosofia contemporânea. }\end{array}$ & 5. Erich Fromm. & $\begin{array}{l}\text { 9. Marshall McLuhan, o } \\
\text { filósofo dos mídia. }\end{array}$ \\
\hline $\begin{array}{l}\text { 2. Hegel, o marco } \\
\text { divisório entre a Filosofia } \\
\text { do passado e do presente. }\end{array}$ & $\begin{array}{l}\text { 6. Bergson, o filósofo da } \\
\text { intuição e da vida. }\end{array}$ & $\begin{array}{l}\text { 10. A cientificidade e seus } \\
\text { representantes na Filosofia. }\end{array}$ \\
\hline $\begin{array}{l}\text { 3. As idéias filosóficas do } \\
\text { século XX - As Filosofias } \\
\text { do indivíduo. }\end{array}$ & $\begin{array}{l}\text { 7. Filosofias da da } \\
\text { consciência histórica. }\end{array}$ & 11. Bertrand Russel. \\
\hline 4. Jean-Paul Sartre. & 8. Herbert Marcuse. & 12. A Filosofia no Brasil. \\
\hline
\end{tabular}

Terceira Parte

\begin{tabular}{|l|l|l|}
\hline $\begin{array}{l}\text { 1. Conceito atual da } \\
\text { Lógica. }\end{array}$ & 5. Cálculo sentencial. & 9. A verdade. \\
\hline 2. A natureza da Lógica. & 6. Sistema dedutivo. & 10. Razão humana. \\
\hline 3. Signos e idéias. & 7. Estruturas lógicas. & \\
\hline $\begin{array}{l}\text { 4. Proposições ou } \\
\text { sentenças. }\end{array}$ & 8. Falácias e sofismas. & \\
\hline
\end{tabular}

Filosofia e Educação - ISSN 1984-9605 - v. 4, no 1, abril-setembro de 2012 
As ilustrações do texto, quando aparecem, tomam a forma de pequenos esquemas explicativos. No final dos capítulos pode ser encontrada uma lista de exercícios para fixação e problematização dos conteúdos expostos. Fechando o texto, temos o item "resposta do problema de inferências corretas" que concerne à terceira parte do texto sobre lógica, bem como uma bibliografia de referência.

Em continuidade a esse enfoque da história da filosófica como centro e como referencial, temos o manual Filosofando: introdução à Filosofia, de Maria Lúcia de Arruda Aranha ${ }^{52}$ e Maria Helena Pires Martins ${ }^{53}$, oferecido nas livrarias pela editora Moderna desde 1986. Em 2003 encontrava-se em sua terceira edição revisada.

Em termos da sua organização, este trabalho traz seus capítulos distribuídos em seis unidades versando sobre "Cultura", "Conhecimento", "Ciência", "Política", "Ética" e "Estética". A abertura de cada unidade é precedida por uma ilustração do universo geral da cultura e comentário correspondente, como forma de situar a temática. Tal estratégia encontra-se presente também nos capítulos, com citação filosófica logo no início e, ora ou outra, por ilustrações comentadas interpondo-se entre os tópicos do texto.

Unidade I

Unidade II

Unidade III

\begin{tabular}{|l|l|l|}
\hline 1. Natureza e cultura. & 4. O que é conhecimento. & $\begin{array}{l}\text { 11. O conhecimento } \\
\text { científico. }\end{array}$ \\
\hline $\begin{array}{l}\text { 2. Pensamento e } \\
\text { linguagem. }\end{array}$ & 5. A ideologia. & $\begin{array}{l}\text { 12. A ciência antiga e } \\
\text { medieval. }\end{array}$ \\
\hline $\begin{array}{l}\text { 3. Trabalho e alienação: } \\
1^{\mathrm{a}} \text { parte }- \text { Trabalho e } \\
\text { lazer; } 2^{\mathrm{a}} \text { parte }-\mathrm{A}\end{array}$ & $\begin{array}{l}\text { 13. A revolução científica } \\
\text { do século XVII. }\end{array}$ \\
\hline
\end{tabular}

${ }^{52}$ Licenciada em Filosofia pela Pontifícia Universidade Católica de São Paulo e atuou como professora de Filosofia na rede particular de ensino de São Paulo.

${ }^{53}$ Professora Livre-Docente da Escola de Comunicações e Artes da Universidade de São Paulo.

Filosofia e Educação - ISSN 1984-9605 - v. 4, no 1, abril-setembro de 2012 


\begin{tabular}{|c|c|c|}
\hline alienação. & & \\
\hline & $\begin{array}{l}\text { 7. Do mito à razão: o } \\
\text { nascimento da Filosofia. }\end{array}$ & $\begin{array}{l}\text { 14. O método científico: } 1^{\mathrm{a}} \\
\text { parte - O método das } \\
\text { ciências da natureza; } 2^{\mathrm{a}} \\
\text { parte - As ciências da } \\
\text { natureza. }\end{array}$ \\
\hline & $\begin{array}{l}\text { 8. A reflexão filosófica: } 1^{\mathrm{a}} \\
\text { parte }-\mathrm{O} \text { que é Filosofia?; } \\
2^{\mathrm{a}} \text { parte }- \text { A Filosofia no } \\
\text { Brasil. }\end{array}$ & 15. As ciências humanas. \\
\hline & $\begin{array}{l}\text { 9. Instrumentos do pensar: } \\
1^{\mathrm{a}} \text { parte }-\mathrm{A} \text { lógica } \\
\text { aristotélica; } 2^{\mathrm{a}} \text { parte }-\mathrm{A} \\
\text { lógica simbólica. }\end{array}$ & \\
\hline & 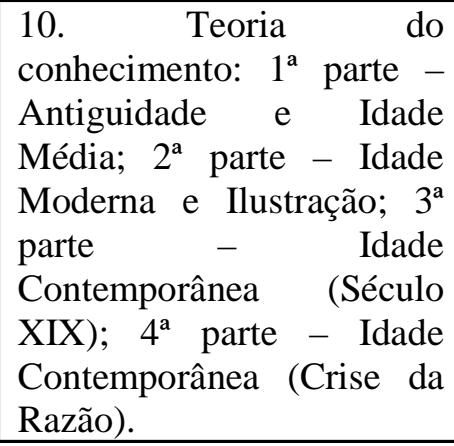 & \\
\hline
\end{tabular}

Unidade IV

16. Introdução à política.

17. A política na Antiguidade e na Idade Média: $1^{\mathrm{a}}$ parte - Grécia Antiga: a política normativa; $2^{\mathrm{a}}$ parte Idade Média: a vinculação da política à religião.

\begin{tabular}{|l|l|l|}
$\begin{array}{l}\text { 18. O política como } \\
\text { categoria autônoma. }\end{array}$ & 25. A liberdade. & $\begin{array}{l}\text { 30. Arte como forma de } \\
\text { pensamento. }\end{array}$ \\
\hline & $\begin{array}{l}\text { 26. A identidade do sujeito } \\
\text { moral: } 1^{\mathrm{a}} \text { parte }-\mathrm{O} \text { corpo; } \\
\text { 19. O liberalismo político. } \\
2^{\mathrm{a}} \text { parte }-\mathrm{O} \text { amor; } 3^{\mathrm{a}} \text { parte } \\
-\mathrm{O} \text { erotismo; } 4^{\mathrm{a}} \text { parte }-\mathrm{A} \\
\text { morte. }\end{array}$ & 31. Funções da arte. \\
\hline 20. A crítica do Estado & 27. Concepções Éticas. & 32. Significado da arte. \\
\hline
\end{tabular}

Filosofia e Educação - ISSN 1984-9605 - v. 4, no 1, abril-setembro de 2012 


\begin{tabular}{|l|l|l|}
\hline $\begin{array}{l}\text { burguês: as teorias } \\
\text { socialistas. }\end{array}$ & \\
\hline $\begin{array}{l}21 . \quad \text { Liberalismo e } \\
\text { socialismo hoje. }\end{array}$ & & 33. Concepções estéticas. \\
\hline 22. Os desvios do poder & & \\
\hline
\end{tabular}

Ao final da maioria destes capítulos ficam as leituras complementares, a partir das quais são sugeridas atividades de desenvolvimento de competências como as de compreensão, interpretação, problematização, bem como questões sobre essas leituras complementares, recomendação de um tema para elaboração pessoal de uma dissertação e sugestão de questões para uma pesquisa a ser apresentada em seminário. $\mathrm{Na}$ parte final do livro, seis tópicos constituem um apoio ao leitor com: sugestões de projetos de trabalho; filmografia comentada com sugestões de filmes para discutir em cada unidade; quadro cronológico com cada período histórico relacionando à Filosofia e ao seu contexto; divisão das correntes filosóficas do século XX; vocabulário; orientação bibliográfica básica e por assunto, e, por fim, um índice onomástico.

Contudo, este material didático não constitui o único trabalho confeccionado por estas autoras. É delas também o texto Temas de Filosofia que será apresentado no tópico que trata da história da Filosofia como referencial dada a opção pela abordagem temática.

Um outro material, presente nesta configuração dos compêndios didáticos, da editora Ática e, em sua décima terceira edição, é o de Marilena Chauí $^{54}$, Convite à Filosofia.

Neste manual, caso o leitor o tome por sua conformação geral, poderá encontrar além de uma introdução em resposta à pergunta "Para que Filosofia?, oito unidades temáticas - "A Filosofia”, "A Razão”, “A verdade”, “A lógica”,

\footnotetext{
${ }^{54}$ Professora de Filosofia na Universidade de São Paulo.
} 
"O conhecimento", "A metafísica", "A ciência", "O mundo da prática" compostas por seus respectivos capítulos:

Unidade I

Unidade II

Unidade III

\begin{tabular}{|l|l|l|}
\hline 1. A origem da Filosofia. & 1. A razão. & 1. Ignorância e verdade. \\
\hline $\begin{array}{l}\text { 2. O nascimento da } \\
\text { Filosofia. }\end{array}$ & 2. A atividade racional. & 2. Buscando a verdade. \\
\hline $\begin{array}{l}\text { 3. Campos de investigação } \\
\text { da Filosofia. }\end{array}$ & $\begin{array}{l}\text { 3. A razão: inata ou } \\
\text { adquirida? }\end{array}$ & $\begin{array}{l}\text { 3. As concepções da } \\
\text { verdade. }\end{array}$ \\
\hline $\begin{array}{l}\text { 4. Principais períodos da } \\
\text { história da Filosofia. }\end{array}$ & $\begin{array}{l}\text { 4. Os problemas do } \\
\text { inatismo e do empirismo: } \\
\text { soluções filosóficas. }\end{array}$ & \\
\hline $\begin{array}{l}\text { 5. Aspectos da Filosofia } \\
\text { contemporânea. }\end{array}$ & $\begin{array}{l}\text { 5. A razão na Filosofia } \\
\text { contemporânea. }\end{array}$ & \\
\hline
\end{tabular}

\begin{tabular}{|c|c|c|}
\hline Unidade IV & Unidade V & Unidade VI \\
\hline 1. Nascimento da lógica. & $\begin{array}{l}\text { 1. A preocupação com o } \\
\text { conhecimento. }\end{array}$ & $\begin{array}{l}\text { As indagações } \\
\text { metafísicas. } \\
\text { 1. O nascimento da } \\
\text { metafísica. }\end{array}$ \\
\hline 2. Elementos da lógica. & 2. A percepção. & $\begin{array}{l}\text { 2. A metafísica de } \\
\text { Aristóteles. }\end{array}$ \\
\hline \multirow[t]{5}{*}{ 3. A lógica simbólica. } & 3. A memória. & $\begin{array}{l}\text { 3. As aventuras da } \\
\text { metafísica. }\end{array}$ \\
\hline & 4. A imaginação. & $\begin{array}{lcc}4 . & \text { A } & \text { ontologia } \\
\text { contemporânea. } & \\
\end{array}$ \\
\hline & 5. A linguagem. & $\begin{array}{l}\text { 5. A Filosofia pós- } \\
\text { metafísica. }\end{array}$ \\
\hline & 6. O pensamento. & \\
\hline & $\begin{array}{l}\text { 7. A consciência pode } \\
\text { conhecer tudo? }\end{array}$ & \\
\hline
\end{tabular}

Unidade VII

Unidade VIII

\begin{tabular}{|l|l|l|}
\hline 1. A atitude científica. & 1. A cultura. & 8. Ética e ciência. \\
\hline 2. A ciência na história. & $\begin{array}{l}\text { 2. A experiência do } \\
\text { sagrado e a instituição do } \\
\text { religião. }\end{array}$ & 9. A vida política. \\
\hline 3. As ciências humanas. & 3. O universo das artes. & $\begin{array}{l}\text { 10. As Filosofias políticas } \\
\text { (1) }\end{array}$ \\
\hline $\begin{array}{l}\text { 4. O ideal científico e a } \\
\text { razão instrumental. }\end{array}$ & $\begin{array}{l}\text { 4. A cultura de massa e a a } \\
\text { indústria cultural. }\end{array}$ & $\begin{array}{l}\text { 11. As Filosofias políticas } \\
\text { (2) }\end{array}$ \\
\hline & 5. A existência Ética. & \begin{tabular}{l} 
12. A política contra a \\
\hline
\end{tabular}
\end{tabular}

Filosofia e Educação - ISSN 1984-9605 - v. 4, no 1, abril-setembro de 2012 


\begin{tabular}{|l|l|l|}
\hline & & servidão voluntária. \\
\hline & 6. A Filosofia moral. & $\begin{array}{l}\text { 13. As experiências } \\
\text { políticas do século XX. }\end{array}$ \\
\hline & 7. A liberdade. & 14. A questão democrática. \\
\hline
\end{tabular}

Entremeando os tópicos dos capítulos podem ser encontradas ilustrações, todas elas acompanhadas de comentários. Ao término de cada unidade são propostas questões relativas à compreensão e fixação dos conteúdos desenvolvidos. Na parte final do livro são expostas duas seções: "Filósofos, cientistas e seu tempo" que exibe, em ordem alfabética, os pensadores, a data de nascimento e morte dos filósofos citados na obra e de outros pensadores importantes para a história da Filosofia, e uma outra "Indicações bibliográficas", na qual são apresentadas obras de apoio, obras que versam sobre o nascimento da Filosofia, obras introdutórias sobre os filósofos e as várias disciplinas filosóficas, coletâneas de seleções de textos com apresentação e comentários e, por fim, leituras recomendadas de textos dos filósofos.

Um outro guia didático, da mesma autora, denominado Filosofia: ensino médio, da série Brasil, publicado pela editora Ática, encontrava-se na época disponível no mercado editorial em sua primeira edição.

Este manual, quanto à sua organização, além de uma introdução, traz duas partes: uma relativa à atividade teórica e outra à atividade prática. Cada uma delas é composta por quatro unidades, sendo na primeira - "A Filosofia", "A Razão", "A verdade", "O conhecimento" e na segunda - "A religião", “As artes", "A Ética", “A política" - com os capítulos que lhes são concernentes:

\begin{tabular}{|c|c|c|c|}
\hline Unidade I & Unidade II & Unidade III & Unidade IV \\
\hline $\begin{array}{l}\text { 1. A atitude } \\
\text { filosófica. }\end{array}$ & 7. A razão. & $\begin{array}{l}\text { 11. Ignorância e } \\
\text { verdade. }\end{array}$ & $\begin{array}{l}\text { 14. A preocupação } \\
\text { com o } \\
\text { conhecimento. }\end{array}$ \\
\hline $\begin{array}{lcc}\text { 2. } \quad \text { O que é } \\
\text { Filosofia. }\end{array}$ & $\begin{array}{lcl}8 . & \text { A } & \text { atividade } \\
\text { racional. } & \\
\end{array}$ & $\begin{array}{l}\text { 12. Buscando a } \\
\text { verdade. }\end{array}$ & 15. A percepção. \\
\hline
\end{tabular}

Filosofia e Educação - ISSN 1984-9605 - v. 4, no 1, abril-setembro de 2012 


\begin{tabular}{|c|c|c|c|}
\hline $\begin{array}{l}\text { 3. A origem da } \\
\text { Filosofia. }\end{array}$ & $\begin{array}{l}\text { 9. A razão: inata ou } \\
\text { adquirida? }\end{array}$ & $\begin{array}{l}\text { 13. As concepções } \\
\text { da verdade. }\end{array}$ & 16. A memória. \\
\hline $\begin{array}{lr}\text { 4. Períodos } & \mathrm{e} \\
\text { campos } & \mathrm{de} \\
\text { investigação } & \text { da } \\
\text { Filosofia grega. } & \end{array}$ & $\begin{array}{l}\text { 10. A razão na } \\
\text { Filosofia } \\
\text { contemporânea. }\end{array}$ & & 17. A imaginação. \\
\hline $\begin{array}{lr}5 . & \text { Principais } \\
\text { períodos } & \text { da } \\
\text { história } & \text { da } \\
\text { Filosofia. } & \\
\end{array}$ & & & 18. A linguagem. \\
\hline $\begin{array}{l}\text { 6. Aspectos da } \\
\text { Filosofia } \\
\text { contemporânea. }\end{array}$ & & & 19. O pensamento. \\
\hline & & & $\begin{array}{l}\text { 20. A } \\
\text { pode } \\
\text { tudo? }\end{array}$ \\
\hline
\end{tabular}

\begin{tabular}{|c|c|c|c|}
\hline Unidade V & Unidade VI & Unidade VII & Unidade VIII \\
\hline $\begin{array}{l}\text { 21. A experiência } \\
\text { do sagrado e a } \\
\text { instituição } \\
\text { religião. }\end{array}$ & $\begin{array}{l}\text { 22. O universo das } \\
\text { artes. }\end{array}$ & $\begin{array}{l}\text { 24. A existência } \\
\text { Ética. }\end{array}$ & 28. A vida política. \\
\hline & $\begin{array}{l}\text { 23. A cultura de } \\
\text { massa e a indústria } \\
\text { cultural. }\end{array}$ & $\begin{array}{l}25 . \text { A Filosofia } \\
\text { moral }\end{array}$ & $\begin{array}{l}\text { 29. As Filosofias } \\
\text { políticas (1) }\end{array}$ \\
\hline & & 26. A liberdade. & $\begin{array}{l}\text { 30. As Filosofias } \\
\text { políticas (2) }\end{array}$ \\
\hline & & 27. Ética e ciência. & $\begin{array}{l}\text { 31. A política contra } \\
\text { a servidão } \\
\text { voluntária. }\end{array}$ \\
\hline & & & $\begin{array}{l}\text { 32. A questão } \\
\text { democrática. }\end{array}$ \\
\hline
\end{tabular}

Diferentemente do Convite à Filosofia, que apresenta questões de compreensão ao final de cada unidade, este as apresenta ao final de cada capítulo. No final é possível usufruir, numa espécie de apêndice, de indicações de filmes, indicações bibliográficas, bem como uma lista de pensadores indicando dados de sua cronologia. 
Como obra desta autora temos ainda Filosofia. Série Novo Ensino Médio, em sua primeira edição, também em parceria com a editora Ática ${ }^{55}$.

Este material ocuparia o lugar intermediário entre estes dois trabalhos apresentados anteriormente.

Feita essa consideração, podemos encontrar neste material desde uma introdução em resposta à pergunta "Para que Filosofia?, como oito unidades temáticas "A Filosofia”, "A Razão", "A verdade”, “O conhecimento", “A lógica", “A metafísica”, “As ciências", "O mundo da prática”, e, ao final, a apresentação de questões e compostas a partir dos seus respectivos capítulos.

Unidade I Unidade II

Unidade III

\begin{tabular}{|l|l|l|}
\hline 1. A origem da Filosofia. & 6. A razão. & 8. Ignorância e verdade. \\
\hline $\begin{array}{l}\text { 2. O nascimento da } \\
\text { Filosofia. }\end{array}$ & $\begin{array}{l}\text { 7. A razão na Filosofia } \\
\text { contemporânea. }\end{array}$ & $\begin{array}{l}\text { 9. As concepções da } \\
\text { verdade. }\end{array}$ \\
\hline $\begin{array}{l}\text { 3. Campos de investigação } \\
\text { da Filosofia. }\end{array}$ & & \\
\hline $\begin{array}{l}\text { 4. Principais períodos da } \\
\text { história da Filosofia. }\end{array}$ & & \\
\hline $\begin{array}{l}\text { 5. Aspectos da Filosofia } \\
\text { contemporânea. }\end{array}$ & & \\
\hline
\end{tabular}

\section{Unidade IV}

Unidade $\mathrm{V}$

Unidade VI

\begin{tabular}{|l|l|l|}
\hline $\begin{array}{l}\text { 10. A preocupação com o } \\
\text { conhecimento. }\end{array}$ & $\begin{array}{l}14 . \text { O nascimento da } \\
\text { lógica. }\end{array}$ & $\begin{array}{l}16 . \quad \text { As indagações } \\
\text { metafísicas. }\end{array}$ \\
\hline 11. A linguagem. & 15. Elementos de lógica. & \\
\hline 12. O pensamento. & & \\
\hline $\begin{array}{l}\text { 13. A consciência pode } \\
\text { conhecer tudo }\end{array}$ & & \\
\hline
\end{tabular}

Unidade VII Unidade VIII

\begin{tabular}{|l|l|l|}
\hline 17. A atitude científica. & 19. A cultura. & $\begin{array}{l}\text { 26. As Filosofias políticas } \\
(1) .\end{array}$ \\
\hline $\begin{array}{l}\text { 18. O ideal científico e a } \\
\text { razão instrumental. }\end{array}$ & $\begin{array}{l}\text { 20. A experiência do } \\
\text { sagrado e a instituição da } \\
\text { religião. }\end{array}$ & $\begin{array}{l}\text { 27. As Filosofias políticas } \\
(2) .\end{array}$ \\
\hline
\end{tabular}

${ }^{55}$ De preço mais acessível.

Filosofia e Educação - ISSN 1984-9605 - v. 4, no 1, abril-setembro de 2012 


\begin{tabular}{|l|l|l|}
\hline & 21. O universo das artes. & $\begin{array}{l}\text { 28. A política contra a } \\
\text { servidão voluntária. }\end{array}$ \\
\hline & 22. A existência Ética. & 29. A questão democrática. \\
\hline & 23; A Filosofia moral. & \\
\hline & 24. A liberdade. & \\
\hline & 25. A vida política. & \\
\hline
\end{tabular}

Sem trazer a riqueza de ilustrações e as mesmas possibilidades quanto às informações presentes nos trabalhos anteriores propostos por essa autora, este manual vem com menos atrativos, isto é, não contempla, ao final, informações a respeito de filósofos, cientistas e seu tempo, e indicações bibliográficas, como é o caso do "Convite à Filosofia", e nem mesmo recomendação de filmes, orientações bibliográficas e uma lista de filósofos, cientistas e seu tempo com é o caso do manual "Filosofia: ensino médio" da série Brasil.

Dando prosseguimento a esta exposição, o que nos vem a seguir é o trabalho de Gilberto Cotrim ${ }^{56}$, Fundamentos da Filosofia: história e grandes temas, da editora Saraiva, na época em sua décima quinta edição reformulada e ampliada.

Para tratar do ensino de Filosofia, o autor estrutura seu trabalho a partir de três unidades denominadas por ele "Fazer Filosofia", "História da Filosofia" e "Grandes Temas Atuais", ou seja, dois grupos de capítulos de caráter mais temático e um outro grupo voltado para os períodos históricos da Filosofia:

Unidade I

Unidade II Unidade III

\begin{tabular}{|l|l|l|}
\hline $\begin{array}{l}\text { 1. Cultura: o cosmo } \\
\text { humano }\end{array}$ & $\begin{array}{l}\text { 5. A aurora da Filosofia: os } \\
\text { pré-socráticos }\end{array}$ & 12. Filosofia da ciência. \\
\hline $\begin{array}{l}\text { 2. Trabalho: liberdade e } \\
\text { submissão. }\end{array}$ & $\begin{array}{l}\text { 6. A Filosofia: o período } \\
\text { clássico greco-romano. }\end{array}$ & 13. Filosofia moral. \\
\hline $\begin{array}{l}\text { 3. Consciência crítica e e } \\
\text { Filosofia. }\end{array}$ & $\begin{array}{l}\text { 7. O pensamento cristão: a } \\
\text { patrística e a escolástica. }\end{array}$ & 14. Filosofia política. \\
\hline $\begin{array}{l}\text { 4. Teoria } \\
\text { conhecimento: do }\end{array}$ & $\begin{array}{l}\text { 8. Filosofia moderna: } \\
\text { novos valores da ciência, }\end{array}$ & 15. Estética. \\
\hline
\end{tabular}

${ }^{56}$ Professor de História graduado pela USP, cursou Filosofia na PUC-SP.

Filosofia e Educação - ISSN 1984-9605 - v. 4, no 1, abril-setembro de 2012 


\begin{tabular}{|l|l|l|}
\hline investigando o saber. & Bacon e Descartes. & \\
\hline & $\begin{array}{l}\text { 9. Filosofia moderna: } \\
\text { empirismo e iluminismo. }\end{array}$ & \\
\hline & $\begin{array}{l}10 . \\
\text { contemporânea I Filosofia }\end{array}$ & \\
\hline & $\begin{array}{l}11 . \\
\text { contemporânea II Filosofia }\end{array}$ & \\
\hline
\end{tabular}

Quanto às ilustrações, este texto dispõe de uma boa variedade acompanhada respectivamente de comentários. Permeando o texto dos capítulos podem ser encontrados recortes de frases de filósofos relacionadas à exposição dos conteúdos. Ao final tanto dos capítulos das unidades temáticas quanto dos capítulos da unidade histórica, ficam algumas seções reservadas: à "análise e entendimento", através das quais podem ser fixados os conteúdos básicos; ao "debate e reflexão", que apresenta propostas de discussão; à "sugestão de filmes", permitindo maior ilustração para as discussões e, por fim, ao "pensar", que se servindo de composições selecionadas de pensadores, filósofos, e de questões no final, permitem ao aluno a contextualização e uma relação mais profunda com a bibliografia especializada. Finalizando a obra podemos encontrar uma bibliografia complementar.

Por fim, um outro material que atende ao objetivo desse tópico trata-se de Introdução à Filosofia: aprendendo a pensar, de Cipriano C. Luckesi ${ }^{57}$ e Elizete S. Passos ${ }^{58}$ editado pela editora Cortez (quarta edição ${ }^{59}$ na época).

57 Licenciado em 1943 na Universidade Católica de Salvador no ano de 1970, mestre em ciências Sociais pela Faculdade de Filosofia e Ciências Humanas da Universidade Federal da Bahia, em 1976, doutor em Filosofia da Educação pela PUC-SP, em 1992, professor adjunto no departamento de Filosofia da Faculdade de Filosofia e Ciências Humanas da Universidade Federal da Bahia e professor adjunto de Metodologia do Trabalho Científico no Departamento de Ciências Humanas e Filosofia da Universidade Estadual de Feira de Santana-Ba.

${ }^{58}$ Licenciada em Filosofia pela Faculdade de Filosofia e Ciências Humanas da Universidade Federal da Bahia, no ano de 1977, mestra e doutora em Educação pela Universidade Federal da Bahia, professora adjunta do departamento de Filosofia da Faculdade de Filosofia e Ciências Humanas da Universidade Federal da Bahia.

${ }^{59}$ Segundo comentário dos editores a respeito do que os autores relataram: "Este livro teve uma primeira versão publicada pelo Centro Editorial e Didático da Universidade Federal da Bahia,

Filosofia e Educação - ISSN 1984-9605 - v. 4, no 1, abril-setembro de 2012 
Através deste manual, numa primeira parte, temos a abordagem da questão do conhecimento e, na segunda parte, o conhecimento filosófico. $\mathrm{Na}$ verdade, ambas se complementam. Conforme se pode ver abaixo, este conteúdo vem distribuído em nove capítulos:

\begin{tabular}{|c|c|c|}
\hline Primeira parte & Segunda parte & \\
\hline $\begin{array}{l}\text { 1. O conhecimento: } \\
\text { significado, processo e } \\
\text { apropriação. }\end{array}$ & $\begin{array}{l}\text { 4. Filosofia: elucidações } \\
\text { conceituais. }\end{array}$ & $\begin{array}{l}\text { 7. Caminhos históricos do } \\
\text { filosofar: Idade Moderna - } \\
\text { o problema do } \\
\text { conhecimento e da } \\
\text { organização social. }\end{array}$ \\
\hline 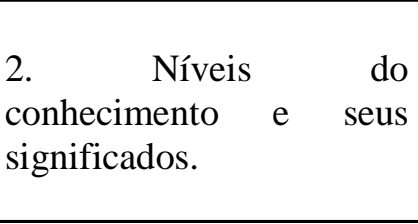 & $\begin{array}{l}\text { 5. Origem e formação das } \\
\text { idéias filosóficas: questões } \\
\text { metodológicas e históricas. }\end{array}$ & $\begin{array}{l}\text { 8. Caminhos históricos do } \\
\text { filosofar: } \\
\text { Contemporânea } \quad-\quad \text { Idade } \\
\text { multiplicidade } \\
\text { problemas emergentes. }\end{array}$ \\
\hline $\begin{array}{l}\text { 3. Conhecimento } \\
\text { verdade. }\end{array}$ & $\begin{array}{l}\text { 6. Caminhos históricos do } \\
\text { filosofar: Idade Antiga e } \\
\text { Média - as questões do } \\
\text { ser, conhecer e agir. }\end{array}$ & $\begin{array}{l}\text { 9. O nosso exercício } \\
\text { brasileiro do filosofar. }\end{array}$ \\
\hline
\end{tabular}

A maneira encontrada pelos autores para expor os conteúdos desses capítulos foi a forma dissertativa trazendo no interior do texto notas informativas, textos da literatura filosófica, atualização das discussões filosóficas e esclarecimentos conceituais. Ao final podem ser encontradas referências bibliográficas que serviram de suporte para o trabalho dos autores.

\section{A história da Filosofia como referencial}

Nesta perspectiva, por um lado, a história da Filosofia deve ser compreendida apenas como referencial ilustrativo para as discussões temáticas, de modo que o

no ano de 1992" (LUCKESI E PASSOS, 2002, p. 10). Por isso, para essa edição, e no sentido de situar o leitor, indicam algumas modificações que foram feitas. No fundo, trata-se de uma revisão de conceitos e vocábulos realizada pelos autores por ocasião da apresentação de uma nova edição do trabalho.

Filosofia e Educação - ISSN 1984-9605 - v. 4, no 1, abril-setembro de 2012 
desenvolvimento dos conteúdos não segue, na sua totalidade, uma orientação cronológica. Por outro lado, como ponto de partida, esta abordagem traz à tona questões que suscitaram e que ainda suscitam o pensamento filosófico através de suas problemáticas. A partir do aporte histórico como referencial ilustrativo, bem como do trabalho filosófico com temas, esses manuais tomam o ensino de Filosofia:

[...] como um esforço de reflexão sobre problemas que desafiam a consciência humana atual. Convida $(m)$ o aluno a fazer Filosofia e apreender o processo do filosofar, tomando como ponto de partida os problemas que ele enfrenta em sua experiência cotidiana. Dessa maneira, parte-se de uma experiência concreta para se chegar à elaboração conceitual que se apresenta como solução, como resposta aos desafios lançados pela experiência (SEVERINO apud SOUZA, 1995, p. 10 - acréscimo nosso).

Em sintonia com esse enfoque, a obra Temas de Filosofia, das autoras Maria Lúcia de Arruda Aranha ${ }^{60}$ e Maria Helena Pires Martins ${ }^{61}$, em sua terceira edição revisada na época - além de uma introdução sobre Filosofia e um apêndice com instrumentos do filosofar, filmografia, orientação bibliográfica e índice de nomes - traz na sua composição três unidades: "A cultura", "O conhecimento", "Os Valores".

Unidade I

\begin{tabular}{|l|l|l|}
\hline 1. O que é cultura? & $\begin{array}{l}\text { 7. O que é o conhecimento: } \\
1^{\mathrm{a}} \text { parte }- \text { Conhecimento e } \\
\text { verdade; } 2^{\mathrm{a}} \text { parte }- \text { Teoria } \\
\text { do conhecimento. }\end{array}$ & $\begin{array}{l}\text { 13. O que são valores: } 1^{\mathrm{a}} \\
\text { parte - Descobrindo os } \\
\text { valores; 2 parte }- \text { A } \\
\text { Filosofia dos valores. }\end{array}$ \\
\hline 2. A condição humana. & 8. O conhecimento mítico. & $\begin{array}{l}\text { 14. Feio ou bonito? } \\
\text { Depende do gosto? }\end{array}$ \\
\hline
\end{tabular}

${ }^{60}$ Licenciada em Filosofia pela Pontifícia Universidade Católica de São Paulo, atuou como professora de Filosofia na rede particular de ensino de São Paulo.

${ }^{61}$ Professora Livre-Docente da Escola de Comunicações e Artes da Universidade de São Paulo.

Filosofia e Educação - ISSN 1984-9605 - v. 4, no 1, abril-setembro de 2012 


\begin{tabular}{|c|c|c|}
\hline 3. O fazer humano. & $\begin{array}{l}\text { 9. O Conhecimento pela } \\
\text { arte. }\end{array}$ & $\begin{array}{l}\text { 15. O que é moral: } 1^{\mathrm{a}} \text { parte } \\
- \text { O sujeito moral; } 2^{\mathrm{a}} \text { parte } \\
\text { - Concepções Éticas. }\end{array}$ \\
\hline 4. Cultura e arte. & $\begin{array}{l}\text { 10. A ideologia: } 1^{\mathrm{a}} \text { parte }- \\
\text { Senso comum e ideologia; } \\
2^{\mathrm{a}} \text { parte }- \text { Ampliando a } \\
\text { discussão. }\end{array}$ & $\begin{array}{l}\text { 16. A construção da } \\
\text { liberdade. }\end{array}$ \\
\hline $\begin{array}{l}5 . \quad \text { Os } \quad \text { meio de } \\
\text { comunicação de massa: } 1^{\text {a }} \\
\text { parte }- \text { A televisão; } 2^{\text {a }} \\
\text { parte - O cinema. }\end{array}$ & $\begin{array}{l}\text { 11. A lógica: } 1^{\mathrm{a}} \text { parte - } \\
\text { Lógica aristotélica; } 2^{\mathrm{a}} \text { parte } \\
\text { - Lógica simbólica. }\end{array}$ & $\begin{array}{l}\text { 17. A afetividade: paixão, } \\
\text { amor e amizade. }\end{array}$ \\
\hline $\begin{array}{l}\text { 6. O mundo globalizado: } \\
1^{\text {a }} \text { parte }-\mathrm{O} \text { que é } \\
\text { globalização; } 2^{\mathrm{a}} \text { parte }- \\
\text { Um novo paradigma. }\end{array}$ & $\begin{array}{l}12 . \quad \mathrm{O} \text { conhecimento } \\
\text { científico: } 1^{\mathrm{a}} \text { parte }-\mathrm{O} \text { que } \\
\text { é ciência; } 2^{\mathrm{a}} \text { parte }-\mathrm{A} \\
\text { ciência e seus métodos; } 3^{\mathrm{a}} \\
\text { parte - Breve histórico da } \\
\text { ciência. }\end{array}$ & 18. O que é política. \\
\hline & & 19. O desafio democrático. \\
\hline & & 20. Violência e concórdia. \\
\hline & & $\begin{array}{l}\text { 21. Concepções de } \\
\text { política. }\end{array}$ \\
\hline
\end{tabular}

A partir de cada um destes capítulos são oferecidas leituras complementares e atividades, com destaque para o "Projeto Filosofia no dia-adia" encontrados ao final de cada unidade. Correspondendo a mesma estratégia das citações e ilustrações presentes no Filosofando, de autoria das mesmas professoras, toda unidade do livro é inaugurada por uma figura ilustrativa e seu respectivo comentário, e cada capítulo recebe inicialmente este tratamento, contando com ilustrações durante seu desenvolvimento. Ao invés de adotar o procedimento de trazer ao final do manual um vocabulário dos principais termos utilizados, as autoras optaram por trazer estas informações em chamadas informativas no decorrer de cada texto.

O texto Construindo Ética e Cidadania Todos os Dias: reflexões sobre temas filosóficos, sociais, políticos, econômicos e históricos, de autoria de 
Mauri Luiz Heerdt ${ }^{62}$, foi lançado em 2001 pela editora Sophos. Encontra-se hoje em sua $5^{\mathrm{a}}$ edição.

Segundo a editora, conforme já salientamos anteriormente, é um material recomendado para o primeiro ano do Ensino Médio e seu conteúdo está distribuído a partir dos seguintes temas:

\begin{tabular}{|c|c|c|c|}
\hline $\begin{array}{l}\text { 1. Para início de } \\
\text { conversa. } \\
\text { 2. Ética: uma } \\
\text { construção } \\
\text { coletiva. } \\
\text { 3. Cidadania é } \\
\text { qualidade de vida. } \\
\text { 4, Construindo } \\
\text { Ética e Cidadania } \\
\text { todos os dias. } \\
\text { 5. A mulher } \\
\text { conquista seu } \\
\text { espaço. } \\
\text { 6. Teatro: cultura } \\
\text { e cidadania. } \\
\text { 7. A saúde está } \\
\text { mal! Índios, } \\
\text { 8. } \\
\text { cidadãos } \\
\text { brasileiros! } \\
9 . \\
\text { descobrimento do } \\
\text { Brasil. } \\
\text { 10. O trabalho: } \\
\text { qual futuro? }\end{array}$ & $\begin{array}{l}\text { 11. Ecologia: } \\
\text { cuidando da casa. } \\
\text { 12. Namoro: um } \\
\text { projeto comum. } \\
\text { 13.Cooperativismo: } \\
\text { a união faz a força. } \\
\text { 14. Curta bem suas } \\
\text { amizades. } \\
\text { 15. No trânsito não } \\
\text { se brinca. } \\
\text { 16. Parabéns, vovós. } \\
\text { 17. Crianças, mas } \\
\text { cidadãos. } \\
\text { 18. O mundo de } \\
\text { barriga vazia. } \\
\text { 19. O racismo fere } \\
\text { a cidadania. } \\
\text { 20. Música: a } \\
\text { linguagem universal. } \\
\text { 21. O direito à terra. }\end{array}$ & $\begin{array}{l}\text { 22. Família: uma } \\
\text { instituição viável? } \\
\text { 23. Direitos! Que } \\
\text { direitos? } \\
24 \text {. Ética e } \\
\text { Cidadania na vida. } \\
\text { 25. } \\
\text { Relacionamento } \\
\text { entre pais e filhos. } \\
\text { 26. } \\
\text { Relacionamento } \\
\text { humano. } \\
\text { 27. Sexualidade: } \\
\text { educar para o } \\
\text { amor. } \\
\text { 28. Alcoolismo: a } \\
\text { vida por um gole. } \\
\text { 29. Uma ilusão. } \\
\text { 30. O adolescente e } \\
\text { as drogas. } \\
\text { 31. Cuidado! A } \\
\text { violência é nossa } \\
\text { vizinha. }\end{array}$ & $\begin{array}{l}\text { 32. Impossível não } \\
\text { ser político. } \\
\text { 33. } \\
\text { Neoliberalismo: } \\
\text { um capítulo do } \\
\text { capitalismo. } \\
\text { 34. Desemprego: o } \\
\text { drama atual. } \\
\text { 35. A dívida } \\
\text { externa. } \\
\text { 36. Globalização: o } \\
\text { mundo em nossa } \\
\text { casa. } \\
\text { 37. Exemplos de } \\
\text { luta pela } \\
\text { Cidadania. } \\
\text { 38. Gandhi: uma } \\
\text { vida sem guerra. } \\
\text { 39. Luther King: } \\
\text { Eu Tenho um } \\
\text { Sonho. }\end{array}$ \\
\hline
\end{tabular}

Os textos destes temas sugerem que tanto educadores quanto alunos construam a Ética a partir da vivência do dia-a-dia. Por este motivo, neste

${ }^{62}$ Mestre pela Universidade Federal de Santa Catarina (UFSC). Professor de Ensino Superior da Unisul.

Filosofia e Educação - ISSN 1984-9605 - v. 4, no 1, abril-setembro de 2012 
material é possível encontrar tanto discussões quanto investigações integradas com os problemas e situações atuais.

Como mais um texto da editora Sophos para o Ensino Médio, temos Eureka: construindo cidadãos reflexivos, de autoria de José Roberto Garcia ${ }^{63} \mathrm{e}$ Valdecir da Conceição Veloso ${ }^{64}$, cujo lançamento foi realizado em 2006.

Seis eixos orientam seus conteúdos:

\begin{tabular}{|l|l|lr|}
\hline $\begin{array}{l}\text { 1. Mito à Filosofia: } \\
\text { instalação da consciência } \\
\text { mítica e a transição da } \\
\text { Filosofia. }\end{array}$ & $\begin{array}{l}\text { 3. Político: estrutura de } \\
\text { poder da sociedade. }\end{array}$ & $\begin{array}{l}\text { 5. Estético: percepção } \\
\text { humana, as relações entre o } \\
\text { belo e o feio. }\end{array}$ \\
\hline $\begin{array}{l}\text { 2. Epistemologia: estudo } \\
\text { sistemático do Ético: refletir sobre a } \\
\text { conhecimento humano. }\end{array}$ & $\begin{array}{l}\text { 4. } \\
\text { conduta humana. }\end{array}$ & $\begin{array}{l}\text { Contemporâneos. } \\
\text { Autores }\end{array}$ \\
\hline
\end{tabular}

De modo geral, trata-se de um livro para o Ensino Médio que preocupouse em oferecer aos alunos uma visão de conjunto dos eixos temáticos, ou campos de estudo da Filosofia.

O trabalho Filosofia: iniciação à investigação filosófica, de autoria de José Auri Cunha ${ }^{65}$, compreende a Filosofia como atividade vital e indissociável da vida cotidiana e, antes de considerar que a história das ideias limita-se ao ordenamento cronológico, aposta na iniciação ao ato de filosofar. Nesse sentido, parte da sugestão de um método de investigação - "Interpretando textos" - abrindo a primeira unidade da obra.

Numa sequência de três partes, contendo quatro capítulos, temos:

\footnotetext{
${ }^{63}$ Graduado em Filosofia. Especialista em Filosofia Política pela Universidade Estadual de Londrina (UEL) e Mestre em Ética pela PUC-SP. Docente no Ensino Médio, Superior e PósGraduação.

${ }^{64}$ Graduado em Filosofia. Especialista em Filosofia Política pela Universidade Estadual de Londrina (UEL) e Mestre em Ética pela PUC-SP. Docente no Ensino Médio, Superior e PósGraduação.

${ }^{65}$ Foi professor de Filosofia da Colégio Equipe de São Paulo e fez seu doutorado em Filosofia na Universidade Estadual de Campinas (UNICAMP).
}

Filosofia e Educação - ISSN 1984-9605 - v. 4, no 1, abril-setembro de 2012 


\begin{tabular}{|l|l|l|}
\hline I - A razão pensa a natureza & II - A razão pensa a cultura & \multicolumn{1}{l}{ III - A razão pensa a razão } \\
\hline $\begin{array}{l}\text { Capítulo 1: A inteligência e } \\
\text { o pensamento }\end{array}$ & $\begin{array}{l}\text { Capítulo 1: Guerras e o } \\
\text { Poder }\end{array}$ & $\begin{array}{l}\text { Capítulo 1: A modernidade } \\
\text { em seu espelho }\end{array}$ \\
\hline $\begin{array}{l}\text { Capítulo 2: A linguagem e } \\
\text { o conhecimento }\end{array}$ & $\begin{array}{l}\text { Capítulo 2: Ideologias e } \\
\text { Justiça }\end{array}$ & $\begin{array}{l}\text { Capítulo 2: A experiência } \\
\text { simbólica e a arte na } \\
\text { cultura tecnológica }\end{array}$ \\
\hline $\begin{array}{l}\text { Capítulo 3: A religião e a } \\
\text { ciência }\end{array}$ & $\begin{array}{l}\text { Capítulo 3: Utopias e e } \\
\text { Democracia }\end{array}$ & $\begin{array}{l}\text { Capítulo 3: As duas fontes } \\
\text { da moralidade ocidental }\end{array}$ \\
\hline $\begin{array}{l}\text { Capítulo 4: Conclusão - A } \\
\text { Filosofia e a natureza }\end{array}$ & $\begin{array}{l}\text { Capítulo 4: Conclusão - A } \\
\text { Filosofia e o homem }\end{array}$ & $\begin{array}{l}\text { Capítulo 4: Conclusão - } \\
\text { filosofando sobre o } \\
\text { filosofar }\end{array}$ \\
\hline
\end{tabular}

Cada capítulo além do desenvolvimento dos seus respectivos conteúdos, traz ao seu final atividades de reflexão crítica, palavras-chave e uma bibliografia comentada.

Convém destacar que, no final do livro, compondo o capítulo "Conclusão - filosofando sobre o filosofar" são apresentadas cinco teses voltadas para o aprofundamento dessa temática.

Dirigido a estudantes, professores e ao público em geral, um outro material de autoria de Sonia Maria Ribeiro de Souza ${ }^{66}$ publicado pela editora FTD com o título Um outro olhar, se propõe a ser uma reflexão didática sobre a Filosofia.

Estruturalmente este livro possui, além de uma introdução, treze capítulos divididos nas seguintes temáticas:

\begin{tabular}{|l|l|l|}
\hline $\begin{array}{l}\text { 1. Filosofia: processo e } \\
\text { produto. }\end{array}$ & $\begin{array}{l}\text { 6. Linguagem,comunicação e } \\
\text { pensamento. }\end{array}$ & $\begin{array}{l}\text { 11. Liberdade: há limites } \\
\text { para o ser humano? }\end{array}$ \\
\hline $\begin{array}{l}\text { 2. O homem: quem é ele, } \\
\text { afinal? }\end{array}$ & 7. Cultura: o saber humano. & $\begin{array}{l}\text { 12. Estética: unidade e } \\
\text { diversidade do belo. }\end{array}$ \\
\hline $\begin{array}{l}\text { 3. Mito, religião e e } \\
\text { Filosofia. }\end{array}$ & 8. Trabalho: o fazer humano. & $\begin{array}{l}\text { 13. Tecnologia: contra ou } \\
\text { a favor do ser humano? }\end{array}$ \\
\hline
\end{tabular}

${ }^{66}$ Doutora em Educação (USP), coordenadora do Programa de Mestrado em Educação da Unip (Universidade Paulista).

Filosofia e Educação - ISSN 1984-9605 - v. 4, no 1, abril-setembro de 2012 


\begin{tabular}{|c|c|}
\hline $\begin{array}{l}\text { 4. Senso comum, ciência } \\
\text { e Filosofia. }\end{array}$ & 9. Política: o poder humano. \\
\hline $\begin{array}{l}\text { 5. O conhecimento: o que } \\
\text { significa? }\end{array}$ & $\begin{array}{l}\text { 10. Ética: a criação dos } \\
\text { valores. }\end{array}$ \\
\hline
\end{tabular}

Inicialmente, cada capítulo recebe uma ilustração e um comentário introdutório. Em seu desenvolvimento podem ser encontrados mapas, esquemas, ilustrações acompanhadas de análise. Na maioria desses capítulos há quadros relativos ao vocabulário e esclarecimentos da temática. Embora se ofereça, no capítulo "Mito, religião e Filosofia", informações que fogem da abordagem da história da Filosofia como referencial, há um paralelo oferecido pela autora entre os períodos históricos, contextos históricos, características da Filosofia e dos filósofos de maior destaque. Cada um dos treze capítulos traz, ao final, a contribuição de uma seção de leituras complementares acompanhadas de questões para refletir e responder, bem como com sugestões de atividades de pesquisa, entrevista, dinâmica de grupo etc.. Nos tópicos finais estão a conclusão, seguida de uma bibliografia referencial e outra complementar.

A seguir temos o compêndio Iniciação ao filosofar: pensando melhor, lançado pela editora Saraiva, na época em sua quarta edição reformulada, e de autoria de Angélica Sátiro ${ }^{67}$ e Ana Miriam Wuensch ${ }^{68}$.

Este manual está organizado em seis unidades - "Filosofar I", "Pensar", "Sentir", "Comunicar", "Agir/Fazer" e "Filosofar II".

\footnotetext{
${ }^{67}$ Graduada em Pedagogia pela UEMG (Universidade Estadual de Minas Gerais), pós-graduada em Temas Filosóficos pela UFMG (Universidade Federal de Minas Gerais), com formação em Filosofia para Crianças junto ao IAPC na Montclair State University - New Jersey - EUA, Mestre em Criatividade Aplicada pela USC (Universidade de Santiago de Compostela Espanha), educadora desde 1980.

${ }^{68}$ Graduada em Filosofia pela UFSM (Universidade Federal de Santa Maria), mestre em Filosofia Política pela UFG (Universidade Federal de Goiás), professora de Filosofia da UnB (Universidade de Brasília), professora formadora de professores e coordenadora de projetos na área de ensino de Filosofia no ensino fundamental e no ensino médio, com ênfase no programa de Filosofia para crianças.
}

Filosofia e Educação - ISSN 1984-9605 - v. 4, no 1, abril-setembro de 2012 
Unidade I

Filosofia?! A Filosofia na escola, na vida, no mundo; A linguagem do amor à sabedoria; Atitudes filosóficas e conhecimento filosófico; $\mathrm{O}$ que o filosofar revela sobre o ser humano?; Ser humano e ser livre; O que descobrimos sobre $\mathrm{o}$ pensar filosofamos?.
Unidade II

Que tipo de pensar é a Filosofia?; De que maneira a Filosofia é um pensar sobre o pensar?; O que o pensar revela sobre o ser humano?; Ligar-se ao mundo pelo pensamento. Compreender é amar?; Pensar o conhecido, pensar o desconhecido; Pensar pode ser uma forma de exercer a liberdade?
Unidade III

O papel do sentimento no conhecimento de sim mesmo; $\mathrm{O}$ que o sentir revela sobre 0 ser humano?; Que relação existe entre sentir e conhecer?; Que sentimentos (páthos) movem o filosofar?; O que é dúvida?; Qual é o sentido do amor?; Amor universal, solidariedade; Liberdade para sentir ou sentir com liberdade?.
Unidade IV O que o comunicar revela sobre o ser humano?; Como comunicamos o que sentimos?; A comunicação é um ato amoroso? O que desejamos com o diálogo?; Por que o diálogo é uma forma profunda de comunicação filosófica?; Como o conhecimento se relaciona com a comunicação?; A comunicação é possível?; A expressão de si mesmo pode se transformar em ação?.

\section{Unidade V} A expressão de si mesmo pode se transformar em ação?; O que o agir revela sobre o ser humano?; E o fazer: o que ele revela sobre o ser humano?; Por que temos desejos, necessidades e vontades?; O que é uma ação amorosa?; Poder e violência; Poder e amor; Ato de alguns, ato de muitos: ações coletivas; $\mathrm{O}$ que é fazer amor?; Erotizando a vida; O que é um ato livre?; Regras, normas e leis; $\mathrm{O}$ fazer pode levar o ser humano para além de si mesmo?; A ação tem um saber próprio?; A esperança; Que relações podemos estabelecer entre o filosofar e o agir/fazer?.

No início de cada unidade uma espécie de teia mostra o modo como o programa foi tecido e quais assuntos serão abordados; cada unidade inicia-se

Filosofia e Educação - ISSN 1984-9605 - v. 4, no 1, abril-setembro de 2012 
com juízos intuitivos, isto é, há um espaço reservado no texto de maneira que o aluno se expresse e anote o que sabe sobre tema proposto; a seguir, muitas outras pessoas, na condição de filósofos, cientistas, jornalistas, poetas, pintores etc., vão falar o que conhecem e pensam a respeito. Neste momento começa o diálogo. Para que ele prossiga foram criadas, ao final, uma série de atividades.

Essas atividades, presentes no interior das unidades, encontram-se divididas em seis seguimentos e chegam a contemplar na sua maioria um lugar com linhas a serem preenchidas pelos alunos conforme as orientações oferecidas, de forma que as exposições, leituras, discussões, descobertas, pesquisas, possam ser devidamente registradas. E são elas: "Suas Questões" que consiste num espaço onde o estudante formula suas próprias indagações; "Pensando Bem" - que consiste em indagações que podem ser respondidas individualmente pelo estudante, ou por pequenos grupos, e que objetivam não só animar os debates em sala de aula, mas também ajudar o estudante a pensar melhor sobre o tema proposto (no final desta atividade há um espaço para que o aluno anote as conclusões do debate); "Atividades Escritas", em que o aluno pode exercitar o seu pensamento e expressá-lo segundo diferentes formatos; "Atividades de Aprofundamento" - que são momentos em que o estudante exercita a pesquisa, passeando por outros caminhos de estudo de maneira a ampliar sua cultura geral (neste item os alunos encontram dicas de sites para pesquisa on-line); "Vocabulário" - de forma que se possa, a todo o momento do processo de ensino, investigar o sentido das palavras e refletir sobre elas (nesta atividade, há a sugestão de que o aluno anote suas descobertas); "Contraponto" - que consiste no momento em que o estudante é convidado a pensar o tema da unidade como um todo, em sua possível negação ou limite. Ao longo do livro, ainda, podem ser encontradas perguntas soltas para instigar o aluno nesta sua conversação com o pensamento.

Filosofia e Educação - ISSN 1984-9605 - v. 4, no 1, abril-setembro de 2012 
Além destes aspectos, esta composição didática traz a indicação de alguns símbolos interativos permeando o texto como: "setas em sentido contrário" que associam o filosofar ao assunto que está sendo abordado; "um trevo" que sugere que se teça uma teia de compreensão sobre determinado assunto; "uma chave", indicando que o fio condutor da teia será o conhecimento etc.; ilustrações, que se encontram presentes por todo seu desenvolvimento e atividades, sejam elas comentadas, ou não. Aproximando-se do final de cada unidade, abre-se ainda um espaço de forma que o aluno exercite, mais uma vez a sua escrita, revendo, através de questões propostas pelas autoras, o seu "caminho de entendimento" e que possa, assim, ensaiar as suas conclusões. Por fim, encerrando cada unidade, há um espaço para uma "agenda" do aluno, um levantamento a respeito da vida e obra dos filósofos da unidade e uma filmografia comentada correspondente à apresentação da mesma unidade. Como referência acadêmica desta produção pode ser encontrada, ao final, uma lista da bibliografia dividida tanto em obras filosóficas, quanto em obras de natureza artística e científica.

Começos de Filosofia. Este é o título do material didático proposto por Roberto Goto ${ }^{69}$.

Em termos da sua arrumação, este texto, além da apresentação, divide-se em quatro partes: "Um começo. O trabalho do conhecimento", "Um meio. Para o exercício da ilustração ${ }^{70}$ ", "Outro começo. A Filosofia por ela mesma" e "Um

\footnotetext{
${ }^{69}$ Licenciou-se em Filosofia entre os anos de 1973 e 1976, na Pontifícia Universidade Católica de Campinas. Foi professor de Filosofia na rede Estadual. É mestre e doutor em Letras pela Universidade Estadual de Campinas (Unicamp). Doutorou-se em Letras e em Educação. Atualmente leciona na Universidade Estadual de Campinas (Unicamp) no Departamento de Filosofia e História da Educação da Faculdade da Educação.

${ }^{70}$ Segundo nota do autor (GOTO, 2000, p. 47), "os textos que compõem essa parte podem (e mesmo devem) ser lidos como subsídios de esclarecimento e exemplificação (numa palavra, ilustração) da primeira parte deste livro: destinam-se a aprofundar a discussão e a reflexão sobre os temas e problemas tratados anteriormente".
}

Filosofia e Educação - ISSN 1984-9605 - v. 4, no 1, abril-setembro de 2012 
fim? Um recomeço? O ser humano e a Filosofia" com seus respectivos grupos de capítulos.

\begin{tabular}{|c|c|c|c|}
\hline Primeira Parte & Segunda Parte & Terceira Parte & Quarta Parte \\
\hline A palavra. & $\begin{array}{l}\text { Conhecimento \& } \\
\text { trabalho }\end{array}$ & Saber é saborear. & Forma \& origem. \\
\hline $\begin{array}{l}\text { As idéias e a } \\
\text { realidade. }\end{array}$ & $\begin{array}{l}\text { Cultura da alma (ou: } \\
\text { materialismo } \\
\text { espiritualismo). }\end{array}$ & $\begin{array}{l}\text { No princípio, era } \\
\text { (=é) o espanto. }\end{array}$ & Para que Filosofia. \\
\hline $\begin{array}{lr}\text { Ciência } & \text { e } \\
\text { Filosofia: } & \text { uma } \\
\text { comparação. } & \\
\end{array}$ & $\begin{array}{l}\text { Homem \& realidade } \\
\text { (ou: pode o mundo } \\
\text { existir sem mim?). }\end{array}$ & $\begin{array}{l}\text { Do amor à } \\
\text { sabedoria. }\end{array}$ & Um epílogo? \\
\hline \multirow[t]{5}{*}{$\begin{array}{l}\text { Lógica: algumas } \\
\text { noções. }\end{array}$} & $\begin{array}{l}\text { Tempo \& espaço, } \\
\text { sentido x razão. }\end{array}$ & $\begin{array}{l}\text { A viagem do } \\
\text { filósofo. }\end{array}$ & \\
\hline & $\begin{array}{ll}\mathrm{O} & \text { intervalo } \\
\text { filosófico } & \\
\end{array}$ & & \\
\hline & $\begin{array}{l}\text { A finalidade da } \\
\text { Ciência. }\end{array}$ & & \\
\hline & $\begin{array}{l}\text { A linguagem da } \\
\text { Filosofia. }\end{array}$ & & \\
\hline & $\begin{array}{lll}\text { Imagens } & & \text { da } \\
\text { Filosofia } & \text { (e } & \text { do } \\
\text { Filósofo). } & & \\
\end{array}$ & & \\
\hline
\end{tabular}

Cada um dos capítulos pode ser caracterizado como pertencente a uma problemática. Em seu enredo, cada problemática encontra-se mesclada com textos filosóficos, literários, esquemas explicativos, elementos da cultura filosófica em geral e questões existenciais, compondo desafios ao pensar contemporâneo. 
Uma outra obra tem como título Para filosofar e reúne diversos autores: Cassiano Cordi ${ }^{71}$, Antonio Raimundo dos $\operatorname{Santos}^{72}$, Elizabeth Maria Bório ${ }^{73}$, Avelino Antônio Correa ${ }^{74}$, Neusa Vendramin Volpe ${ }^{75}$, Ana Maria Laporte ${ }^{76}$, Sílvia Maria de Araújo ${ }^{77}$, Anita Helena Schelesener ${ }^{78}$, Luiz Carlos Ribeiro ${ }^{79}$, Dimas Floriani ${ }^{80}$ e Maria José Justino ${ }^{81}$. Lançada pela editora Scipione encontrava-se na época em sua $4^{a}$ edição.

\footnotetext{
${ }^{71}$ Licenciatura em Filosofia pela PUC-PR. Mestrado em Filosofia da educação pela PUC-SP e em teologia pela PUC-RJ. Doutorado em Filosofia pela Universidade Gama Filho e Pósdoutorado em Ética pela Universidade de Filosofia de Trieste - Itália. Membro da Academia Brasileira de Filosofia. Desde 1970 leciona na Universidade Federal do Paraná - UFPR.

${ }^{72}$ Mestrado em Filosofia das ciências humanas pela PUC-SP. Professor de Ética e metodologia da pesquisa científica na PUC-PR.

${ }^{73}$ Especialização em Ética na Fundação Escola de Sociologia e Política de São Paulo - USP e em teoria do conhecimento na Universidade Federal do Paraná. Coordenadora do Curso de Filosofia (1993-5) e professora de Ética do Departamento de Filosofia da Universidade do Paraná.

${ }^{74}$ Licenciatura em Filosofia e bacharelado em teologia. Professor de Filosofia no ensino médio. Editor de livros didáticos.

75 Graduação em Filosofia e estudos sociais e mestrado em educação. Professora de antropologia filosófica e Filosofia e coordenadora do curso de Filosofia da PUC-PR.

${ }^{76}$ Graduação em Filosofia e pedagogia, com especialização em metodologia do ensino superior e Filosofia do direito. Foi professora da PUC-PR e da Faculdade de Administração e Economia de Curitiba. Leciona na Faculdade Arquidiocesana de Filosofia de Curitiba.

${ }_{77}$ Mestrado em história social pela UFPR. Doutorado em ciências da comunicação pela ECA/USP. Pós-doutorado em sociologia do trabalho pela Universidade de Milão. É professora do Departamento de Ciências Sociais (Programa de Pós-Graduação em Sociologia) e diretora do Setor de Ciências Humanas, Letras e Artes da Universidade Federal do Paraná.

${ }^{78}$ Licenciatura em Filosofia pela Universidade Federal do Paraná. Mestrado em Filosofia da educação pela PUC-SP. Doutoranda em história pela Universidade Federal do Paraná. Professora do Departamento de Filosofia da Universidade Federal do Paraná.

${ }^{79}$ Formado em história pela Universidade Federal do Paraná, com mestrado pela Universidade de São Paulo e doutorado pela Université de la Nouvelle Sorbonne - Paris III. Há muitos anos ministra cursos de atualização para professores da rede de ensino fundamental e médio. Professor de história na Universidade Federal do Paraná.

${ }^{80}$ Doutorado em sociologia pela Universidade Católica de Louvain. Professor titular de teoria sociológica, atuando na Universidade Federal do Paraná nos cursos de graduação de ciências sociais, de mestrado de sociologia das organizações e de doutorado interdisciplinar de meio ambiente e desenvolvimento. Professor visitante do IUED (Genebra, Suíça).

${ }^{81}$ Formada em Filosofia pela Universidade Federal do Paraná e em pintura pela Escola de Música e Belas-Artes do Paraná - EMBAP. Mestrado em Filosofia da educação pela PUC-SP e doutorado em Estética e ciências da arte pela Universidade de Paris VIII. Professora de história da arte na EMBAP.
}

Filosofia e Educação - ISSN 1984-9605 - v. 4, no 1, abril-setembro de 2012 
Nela são inaugurados onze capítulos sobre o filosofar a partir das seguintes temáticas:

\begin{tabular}{|c|c|}
\hline 1. O que é filosofar? Do mito à razão ${ }^{82}$. & 7. As várias faces da ideologia ${ }^{83}$. \\
\hline $\begin{array}{l}\text { 2. Conhecer ou não conhecer, eis a } \\
\text { diferença } \mathrm{a}^{84} \text {. }\end{array}$ & 8. Cidadania e política ${ }^{85}$ \\
\hline 3. A moral nossa de cada dia $^{86}$. & 9. Trabalho e Realização ${ }^{87}$. \\
\hline 4. O desafio da liberdade ${ }^{88}$. & 10. Tecnologia e Sociedade ${ }^{89}$. \\
\hline 5. Amar, o verbo da vida ${ }^{90}$. & 11. A admirável complexidade da $\operatorname{arte}^{91}$. \\
\hline 6. Indivíduo e Sociedade ${ }^{92}$. & \\
\hline
\end{tabular}

Todas essas temáticas vêm acompanhados de roteiro de estudo, seção para refletir, seção pra ler e debater, sugestões de livros, filmes e referências bibliográficas. Há ilustrações comentadas abrindo cada uma delas e ilustrações comentadas, fotos e esquemas permeando todos os textos. $\mathrm{Na}$ parte final encontra-se um glossário com os principais verbetes trabalhados, um apêndice com informações adicionais sobre os principais filósofos e estudiosos destacados em cada temática.

O manual que temos agora se intitula Ética e cidadania: caminhos da Filosofia, lançado pela editora Papirus e que se encontra em sua décima primeira edição revisada e atualizada. São seus autores Sílvio Gallo ${ }^{93}$

\footnotetext{
${ }^{82}$ Autoria de Cassiano Cordi.

${ }^{83}$ Autoria de Silvia Maria de Araújo.

${ }^{84}$ Autoria de Antonio Raimundo dos Santos.

${ }^{85}$ Autoria de Anita Helena Schlesener.

${ }^{86}$ Autoria de Elizabeth Maia Bório.

${ }^{87}$ Autoria de Luiz Carlos Ribeiro.

${ }^{88}$ Autoria de Avelino Antonio Correa.

${ }^{89}$ Autoria de Dimas Floriani.

${ }^{90}$ Autoria de Neusa Vendramin Volpe e Ana Maria Laporte.

${ }^{91}$ Autoria de Maria José Justino.

${ }^{92}$ Autoria de Sílvia Maria de Araújo.

${ }^{93}$ Licenciado em Filosofia pela PUC-Campinas, mestre e doutor em Filosofia da Educação pela Unicamp. Atualmente é professor do Departamento de Filosofia e História da Educação da Unicamp.
}

Filosofia e Educação - ISSN 1984-9605 - v. 4, no 1, abril-setembro de 2012 
(coordenador), Márcio Mariguela ${ }^{94}$, Paulo Roberto Brancatti ${ }^{95}$, Márcio Danelon $^{96}$, Luís Carlos Gonçalves ${ }^{97}$, Carlos Henrique Cypriano ${ }^{98}$.

Considerando a sua organização, a produção deste trabalho possui uma primeira apresentação "para quem ensina Filosofia", bem como informações "para quem estuda Filosofia", ambas elaboradas pelo grupo de estudos sobre ensino de Filosofia (Gesef) que assina esta proposta. Seu conteúdo encontra-se exposto num conjunto de onze temas:

\begin{tabular}{|c|c|}
\hline 1. A Filosofia e o conhecimento ${ }^{99}$. & 7. Sexualidade: o nome da coisa ${ }^{100}$. \\
\hline 2. Política e Cidadania ${ }^{101}$. & 8. A Liberdade ${ }^{102}$. \\
\hline 3. A ideologia ${ }^{103}$. & 9. Estética: arte e vida cotidiana ${ }^{104}$. \\
\hline $\begin{array}{l}\text { 4. Alienação: (des)humanização do } \\
\text { homem no trabalho }{ }^{105} \text {. }\end{array}$ & 10. Estética de $\mathrm{Si}^{106}$. \\
\hline 5. Ética e Civilização ${ }^{107}$. & $\begin{array}{l}\text { 11. Ética e Cidadania na Sociedade } \\
\text { Tecnológica }{ }^{108} \text {. }\end{array}$ \\
\hline 6. $\mathrm{OCO}$ & \\
\hline
\end{tabular}

${ }^{94}$ Licenciado em Filosofia pela PUC-Campinas, mestre em Filosofia da Educação e doutor em Psicologia da Educação pela Unicamp. Foi coordenador do curso de Filosofia da Unimep e, atualmente, é professor do Departamento de Filosofia dessa mesma universidade.

${ }^{95}$ Licenciado em Filosofia pela PUC-Campinas e em Educação Física pela Unimep. É mestre em Filosofia da Educação pela Unimep e professor do Departamento de Educação da Unesp (Presidente Prudente).

${ }_{96}$ Licenciado em Filosofia pela Unimep. Mestre e Doutor em Filosofia da Educação pela Unicamp. Atualmente é professor na Faculdade de Educação da Universidade Federal de Uberlândia.

${ }^{97}$ Licenciado em Filosofia pela Unimep. É professor de Filosofia no ensino médio e assessor político.

${ }^{98}$ Licenciado em Filosofia pela Unimep. É também agente cultural.

${ }^{99}$ Autoria de Paulo Roberto Brancatti.

${ }^{100}$ Autoria de Márcio Mariguela.

${ }^{101}$ Autoria de Sílvio Gallo e Luís Carlos Gonçalves.

${ }^{102}$ Autoria de Sílvio Gallo.

${ }^{103}$ Autoria de Sílvio Gallo.

${ }^{104}$ Autoria de Márcio Danelon e Carlos Henrique Cypriano.

${ }^{105}$ Autoria de Paulo Roberto Brancatti e Márcio Danelon.

${ }^{106}$ Autoria de Márcio Mariguela.

${ }^{107}$ Autoria de Márcio Mariguela.

${ }^{108}$ Autoria de Sílvio Gallo.

${ }^{109}$ Autoria de Sílvio Gallo e Paulo Roberto Brancatti.

Filosofia e Educação - ISSN 1984-9605 - v. 4, no 1, abril-setembro de 2012 
Cada um desses temas é inaugurado por um pequeno recorte da vida cotidiana de modo que o estudante possa se ambientar com a problemática filosófica a ser desenvolvida. Os textos, através de uma linguagem acessível, tentam trazer elementos do pensar filosófico para um debate de questões contemporâneas. No final de cada tema desenvolvido há a sugestão de textos complementares de diversos registros (filosóficos, científicos, artísticos); propostas de atividades de pesquisa como entrevista, análise, discussão, questões; indicações de leitura e sugestões de atividades a partir de músicas e filmes.

O manual que vem a seguir intitula-se Filosofia para jovens: uma iniciação à Filosofia. É de autoria de Maria Luiza Silveira Teles ${ }^{110}$ (2001). Seu lançamento foi realizado pela editora Vozes e encontrava-se em sua décima terceira edição.

Seus conteúdos dispõem, além de prefácio e uma bibliografia final, de treze capítulos em que são desenvolvidos os temas:

\begin{tabular}{|l|l|}
\hline 1. O ato de filosofar & 8. Ter e ser \\
\hline 2. O conhecimento e a reflexão lógica & 9. A felicidade \\
\hline 3. Valores éticos e estéticos & 10. A crise contemporânea \\
\hline 4. A liberdade & 11. Ideologia e alienação \\
\hline 5. A morte & 12. O homem integral \\
\hline 6. Religião e Religiosidade & 13. A história da Filosofia \\
\hline 7. Amor e paixão & \\
\hline
\end{tabular}

Cada qual desses temas encontra-se descerrado por uma pequena epígrafe de um pensador, artista, ou cientista de referência e, vez ou outra, vêm acompanhados de um resumo das ideias propostas. Em todos os temas há um

${ }^{110}$ Formada em Pedagogia, Inglês e Terapia Reikiana com pós-graduação em Psicologia e Sociologia, vem, hoje, trabalhando num projeto novo: iniciar crianças e jovens na Filosofia. Atualmente é terapeuta Reiki, consultora pedagógica, tradutora, conferencista, professoras de cursos de aperfeiçoamento, extensão e pós-graduação.

Filosofia e Educação - ISSN 1984-9605 - v. 4, no 1, abril-setembro de 2012 
conjunto de atividades finais na forma de perguntas auxiliando na confecção de debates, seminários, painéis, workshops, bem como a indicação de leituras de autoria variada.

Encerrando esta lista dos manuais de ensino de Filosofia direcionados ao Ensino Médio, temos o livro de autoria de Charles Feitosa ${ }^{111}$ Explicando a Filosofia com Arte, cujo lançamento foi realizado pela editora Ediouro em 2004.

Além da introdução e dos aspectos finais como a conclusão, a bibliografia e o crédito das ilustrações, o seu conteúdo encontra-se distribuído em sete temas “Um Olhar Diferente”, “Adeus ao Real”, “A Ciência Pensa?”, “Em torno da Natureza", “A Arte de Pensar a Arte”, "E o Amor, Então Também Acaba?" e "Pensamentos Mortais".

Tema I Tema II Tema III

\begin{tabular}{|c|c|c|}
\hline 1. Mora na Filosofia. & 1. Grandes Aventuras. & 1. Tecnofobia. \\
\hline $\begin{array}{l}\text { 2. Disposição para a } \\
\text { Vertigem. }\end{array}$ & $\begin{array}{l}\text { 2. Teorias Fundamentais do } \\
\text { Real. }\end{array}$ & $\begin{array}{l}\text { 2. Filosofia e Ciência: } \\
\text { Ligações perigosas. }\end{array}$ \\
\hline 3. Imagens do Filósofo. & $\begin{array}{l}\text { 3. Vantagens } \\
\text { Desvantagens do Realismo. }\end{array}$ & 3. A Ciência Moderna. \\
\hline $\begin{array}{l}\text { 4. Arte de Criar } \\
\text { Conceitos. }\end{array}$ & 4. Adeus ao Real. & $\begin{array}{l}\text { 4. Teorias Alternativas } \\
\text { sobre a Ciência. }\end{array}$ \\
\hline 5. Um Olhar Diferente. & & 5. A Ciência Pensa? \\
\hline $\begin{array}{lcc}6 . & \text { A } & \text { Filosofia como } \\
\text { Pensamento do Concreto. }\end{array}$ & & \\
\hline 7. Pensar é Viajar. & & \\
\hline
\end{tabular}

\begin{tabular}{|l|ll|l|l|l|}
\multicolumn{1}{c}{ Tema IV } & \multicolumn{2}{c}{ Tema V } & \multicolumn{2}{c|}{ Tema VI } \\
\hline $\begin{array}{l}\text { 1. Pequena } \\
\text { História da Idéia } \\
\text { de Natureza. }\end{array}$ & $\begin{array}{l}\text { 1. O Senso e o } \\
\text { Sensível. }\end{array}$ & $\begin{array}{l}\text { 1. A Força das } \\
\text { Paixões. }\end{array}$ & 1. A Gente Morre. \\
\hline
\end{tabular}

${ }^{111}$ Doutor em Filosofia pela Universidade de Freiburg, Alemanha. Desde 2002 está empenhado no projeto de uma "Filosofia pop", que envolve a associação de conceitos com imagens, em uma linguagem acessível e bem humorada, sem perder o rigor e a densidade inerentes à Filosofia. Como professor e pesquisador na pós-graduação em artes cênicas da UNIRIO, atua principalmente nas áreas de Estética e fenomenologia.

Filosofia e Educação - ISSN 1984-9605 - v. 4, no 1, abril-setembro de 2012 


\begin{tabular}{|c|c|c|c|}
\hline $\begin{array}{l}\text { 2. Da Utopia ao } \\
\text { Enigma. }\end{array}$ & $\begin{array}{l}\text { 2. A Verdade na } \\
\text { Arte. }\end{array}$ & 2. O Tédio. & $\begin{array}{lrrr}\text { 2. } & \text { O } & \text { Medo } & \text { da } \\
\text { Morte. } & & \end{array}$ \\
\hline $\begin{array}{l}\text { 3. A Sabedoria } \\
\text { dos Animais. }\end{array}$ & $\begin{array}{l}\text { 3. A Utilidade da } \\
\text { Arte. }\end{array}$ & $\begin{array}{l}\text { 3. Pensando o } \\
\text { Amor. }\end{array}$ & $\begin{array}{lcl}3 . & \text { A } & \text { Atitude } \\
\text { Soberana. } & \end{array}$ \\
\hline $\begin{array}{l}\text { 4. Quem Tem } \\
\text { Medo do Corpo? }\end{array}$ & $\begin{array}{lcc}4 . \quad \mathrm{O} & \text { Efeito } \\
\text { Purificador. } & \\
\end{array}$ & $\begin{array}{l}\text { 4. O Amor a } \\
\text { Serviço da Razão. }\end{array}$ & $\begin{array}{l}\text { 4. A Morte do Outro } \\
\text { e a Minha Morte. }\end{array}$ \\
\hline $\begin{array}{lr}\text { 5. Ninguém } & \text { Está } \\
\text { a Salvo } & \text { e } \\
\text { Ninguém } & \text { Está } \\
\text { Perdido. } & \end{array}$ & $\begin{array}{lccc}\text { 5. O Fim } & \text { da } \\
\text { Estética } & & \end{array}$ & $\begin{array}{l}\text { 5. O Mito da } \\
\text { Unidade } \\
\text { Originária. }\end{array}$ & $\begin{array}{l}\text { 5. A Comunidade } \\
\text { dos Mortais. }\end{array}$ \\
\hline & $\begin{array}{l}6 . \quad \text { Beleza } \\
\text { fundamental? }\end{array}$ & $\begin{array}{l}\text { 6. E o Amor, } \\
\text { Então, } \\
\text { Acaba? }\end{array}$ & $\begin{array}{ll}\text { 6. Somente } & \text { os } \\
\text { Singulares } & \text { se } \\
\text { Sentem } & \\
\text { Responsáveis. } & \\
\end{array}$ \\
\hline & & $\begin{array}{l}\text { 7. A Fertilidade } \\
\text { dos Mortais. }\end{array}$ & 7. Alegria de Viver. \\
\hline
\end{tabular}

Esse manual, talvez porque se aventura no mundo da arte, exibe um material gráfico bastante requintado e ganha notoriedade nesta nossa exposição pela variedade e ocasionalidade das ilustrações, bem como por seus quadros explicativos intercalando escritos que prezam tanto por uma variação temática quanto por questões voltadas a problemas da atualidade.

\section{Referências bibliográficas ${ }^{112}$}

ARANHA, M. L. de A.; MARTINS, M. H. P. Filosofando: introdução à Filosofia. $3^{\text {a }}$ ed. revista. São Paulo: Moderna, 2003.

. Temas de Filosofia. $3^{\mathrm{a}}$ ed. rev. São Paulo: Moderna, 2005.

CARVAlHO, A. A. de. Teófilo II: A Arte da Filosofia: lições de Filosofia para jovens. Goiânia: Terra, 2000.

CHALITA, G. Vivendo a Filosofia. 2a ed. São Paulo: Atual, 2004.

CHAUÍ, M. Convite à Filosofia. 13ª ed. São Paulo: Ática, 2005a. . Filosofia: ensino médio. São Paulo: Ática, 2005b.

${ }^{112}$ Alguns títulos presentes na bibliografia não foram encontrados para que pudessem compor a exposição, mas foram aqui elencados a título de informação.

Filosofia e Educação - ISSN 1984-9605 - v. 4, no 1, abril-setembro de 2012 
. Filosofia. Série Novo Ensino Médio. Volume único. $1^{\mathrm{a}}$ ed. São Paulo: Ática, 2004.

CHAUÍ, M.; FERES, O.; LEOPOLDO E SILVA, F.; MARICONDA, P. R. de.; OLIVEIRA, A. M.; NASCIMENTO, M. M.; PAULA ASSIS, J. E.; PLASTINO, C. E.; NASCIMENTO, C. A. R. de.; WATANABE, L. Primeira Filosofia: lições introdutórias: sugestões para o Ensino Básico de Filosofia. $6^{a}$ ed. São Paulo: Brasiliense, 1986.

COTRIM, G. Fundamentos da Filosofia: história e grandes temas. $15^{\text {a }}$ ed. reform. e ampl. São Paulo: Saraiva, 2003.

CORDI; SANTOS; BÓRIO; CORREA; VOLPE; LAPORTE; ARAÚJO; SCHLESENER; RIBEIRO; FLORIANI; JUSTINO. Para filosofar. $4^{a}$ ed. São Paulo: Scipione, 2001.

CUNHA, J. A. Filosofia: iniciação à investigação filosófica. São Paulo: Atual, 1992.

CYRINO, H. Filosofia Hoje. $2^{a}$ ed. Campinas: Papirus, 1986.

FEITOSA, C. Explicando a Filosofia com Arte. Rio de Janeiro: Ediouro, 2004.

GALLO, S. (Coord.) Ética e Cidadania: caminhos da Filosofia. $11^{a}$ ed. rev. e atualizada. Campinas: Papirus, 2003.

GARCIA, J. R.; VELOSO, V.C. Eureka: construindo cidadãos reflexivos. Florianópolis: Sophos, 2006.

GOTO, R. A. Comeģos da Filosofia. Campinas: Átomo, 2000.

HEERDT, M. L. Pensando para viver: alguns caminhos da Filosofia. $5^{\text {a }}$ ed. Florianópolis: Sophos, 2005. . Construindo Ética e Cidadania todos os dias: reflexões sobre temas filosóficos, sociais, políticos, econômicos e históricos. $5^{\text {a }}$ ed. Florianópolis: Sophos, 2005. LAJOLO M.; ZILBERMAN, R. A formação da leitura no Brasil. São Paulo: Ática, 2003.

Filosofia e Educação - ISSN 1984-9605 - v. 4, no 1, abril-setembro de 2012 
LEOPOLDO e SILVA, Franklin. História da Filosofia: centro ou referencial?

In: NIELSEN NETO, Henrique (Org.) Ensino de Filosofia: coletânea de textos distribuídos nos $1^{\circ}$ e $2^{\circ}$ encontros estaduais de professores de Filosofia, realizados em Santos, 1985/6. São Paulo: SEAF, 1986.

LUCKESI, C. C.; PASSOS, E. S. Introdução à Filosofia: aprendendo a pensar. $4^{a}$ ed. São Paulo: Cortez, 2002.

MAGEE, B. História da Filosofia. $3^{\mathrm{a}}$ ed. São Paulo: Loyola, 2001.

MANNION, J. O Livro Completo de Filosofia: entenda os conceitos básicos dos grandes pensadores: de Sócrates a Sartre. São Paulo: Madras, 2005.

MONDIN, B. Introdução à Filosofia: problemas, sistemas, autores, obras. $12^{\text {a }}$ edição, São Paulo: Paulus, 2001.

MORRA, G. Filosofia para todos. São Paulo: Paulus, 2001.

NUNES, C. A. Aprendendo Filosofia. 2a ed. Campinas: Papirus, 2001.

REZENDE, A. (Org.). Curso de Filosofia: para professores e alunos dos cursos de segundo grau e de graduação. 13 ${ }^{\mathrm{a}}$ ed. Rio de Janeiro: Jorge Zahar Ed., 2005. SÁTIRO, A.; WUENSCH, A. M. Pensando melhor - iniciação ao filosofar. $4^{\text {a }}$ ed. reform. São Paulo: Saraiva, 2003.

SEVERINO, A. J. Filosofia. São Paulo: Cortez, 1994.

SOUZA, S. M. R. de. Um outro olhar: Filosofia. São Paulo: FTD, 1995.

TELES, A. X. Introdução ao Estudo de Filosofia. 34ª ed. São Paulo, 2001.

TELES, M. L. S. Filosofia para crianças e adolescentes. Petrópolis: Vozes, 1999. 